\title{
أثر العنوان في إعادة إنتاج الدلالة
}

/ السيد نعيم شريف محمد ناصر

أستاذ نظرية الأدب المساعد

قسم اللغة العربية وآدابها

كلية الآداب - جامعة المنصورة

\section{الملخص:}

يهدف هذا البحث إلى المقارنة بين الروايتين "إعدام قطار" و "وما زال القطار يجري"،

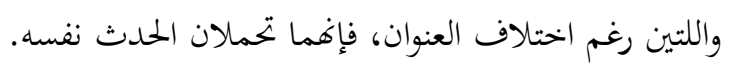

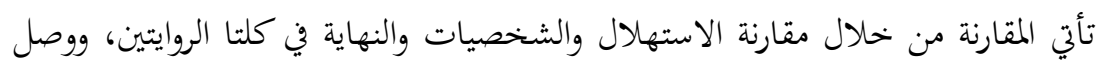

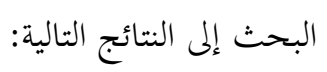

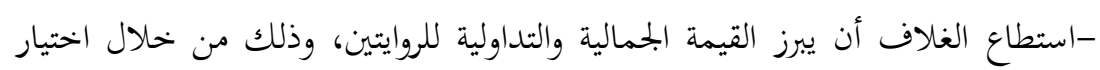

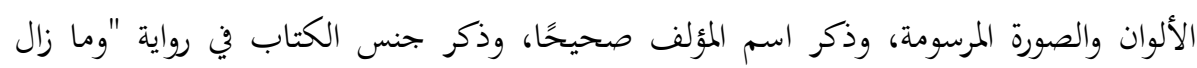
القطار يجري".

- يحمل عنوان رواية "إعدام قطار" تلك الدلالة المتشائمة، وهو ما ظهر في غهاية الحدث

عندما ارتبط إعدام القطار بموت صبري الشخصية الرئيسة.

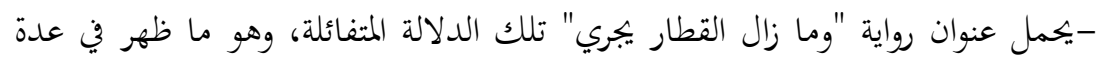

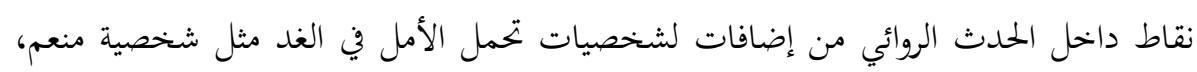

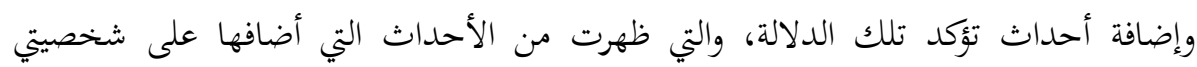
"حمودة وشهيرة"، وتخصيص التعليم للفتيات الثلاثة، والتي تؤكد أهمية التعليم.

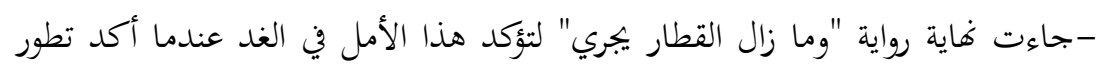
أساليب الزراعة، وموت سلبيات البحتمع بموت القطار.

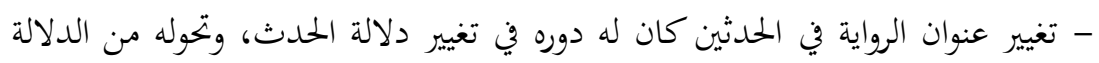
المتشائمة إلى الدلالة المتفائلة. - يرجع البحث إعادة كتابة رواية "إعدام قطار" مرة أخرى بعد عشر سنوات، وتغيير

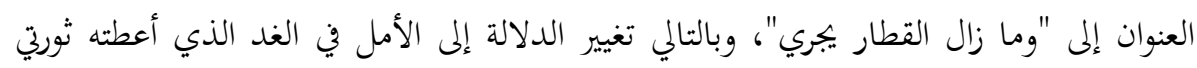

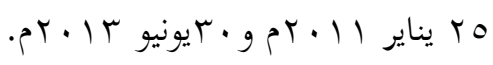




\section{An Abstract}

Title effect on reproduction of significance

This research aims to compare the two novels "execution of a train" and "and the train is still running", which, despite the difference in the title, bear the same event.

The comparison comes by comparing the initiation, the characters, and the ending in both accounts, and the research reached the following results:

- The cover was able to highlight the aesthetic and deliberative value of the two versions, by choosing the colors and the picture painted, and mentioning the author's name correctly, and mentioning the gender of the book in the novel "The train is still running".

- The title of the novel "Executing a Train" bears the pessimistic significance, which appeared at the end of the event when the execution of the train was associated with the death of Sabri, the main character.

- The title of the novel "And the train is still running" bears that optimistic indication, which appeared in several points inside the narrative event, including additions to characters carrying hope for tomorrow, such as the character of Menem, and the addition of events that confirm that indication, which emerged from the events that he added to my character "Hammouda". Shahira, "the allocation of education to the three girls, which stresses the importance of education. 
-The end of the novel "And the train is still running" came to confirm this hope for tomorrow when it confirmed the development of farming methods, and the death of society's negatives with the death of the train.

- Changing the title of the novel in the two events had a role in changing the significance of the event, and its transformation from a pessimistic connotation to an optimistic connotation.

- The research returns the rewriting of the novel "Executing a Train" again after ten years, and changing the title to "and the train is still running", thus changing the significance to hope for the tomorrow that gave rise to the January 25, 2011 and June 30, 2013 revolutions.

\section{مقدمة}

يشير الدكتور صلاح فضل في كتابه "إعادة إنتاج الدلالة" إلى دور القارئ في إعادة إنتاج

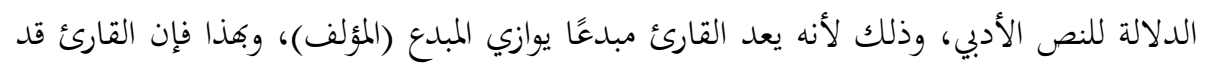

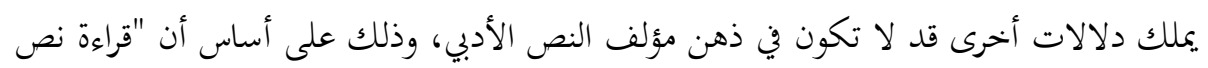

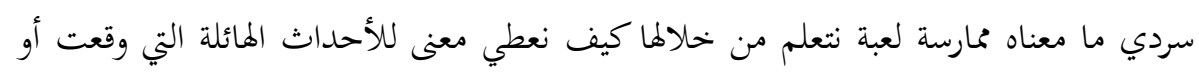

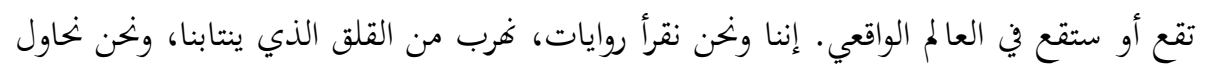

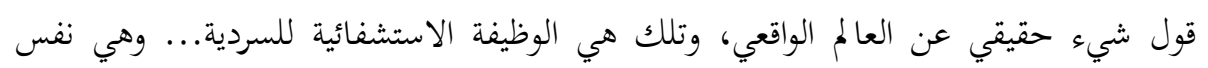

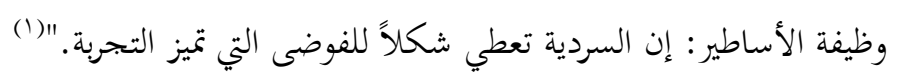

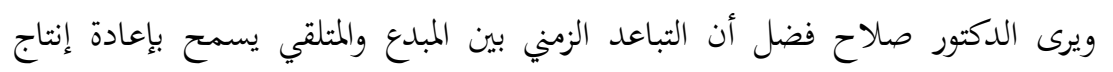

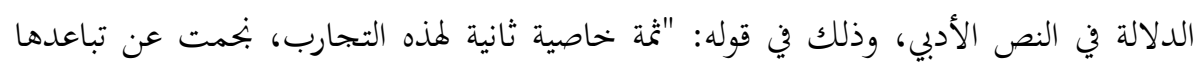

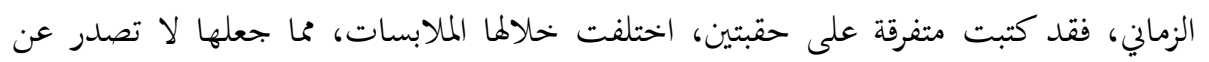

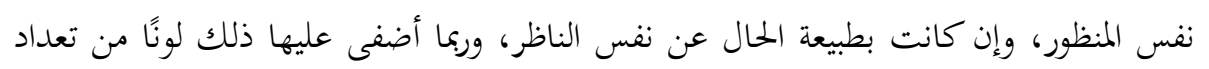

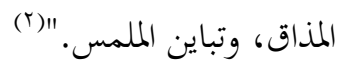


لكن في روايتي "إعدام قطار" و "وما زال القطار يجري" للروائي السعيد بخم نحن أمام روائي آثر أن يعيد إنتاج الدلالة بنفسه، لأن الروايتين عبارة عن حدث واحدة، لكن برؤية مختلفة، فنحن في هاتين الروايتين نتعامل مع هذا القطار الفرنساوي الذي كان يسير من خط القرية الأم "تلبانة" ليصل بالركاب إلى المنصورة، في رحلة شاقة للركاب، لكن السعيد بجم في الرواية الثانية "وما زال القطار يجري" أراد أن يطرح هذا الحدث برؤية أخرى متفائلة عن الحدث في "إعدام

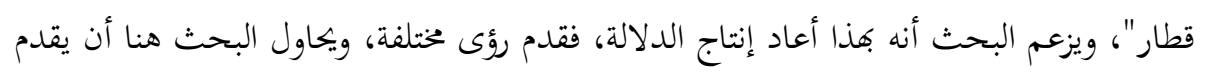
هذه الرؤى المختلفة بين الروايتين. أولاً: :تفاصيل الغلاف الخارجي للروايتين:

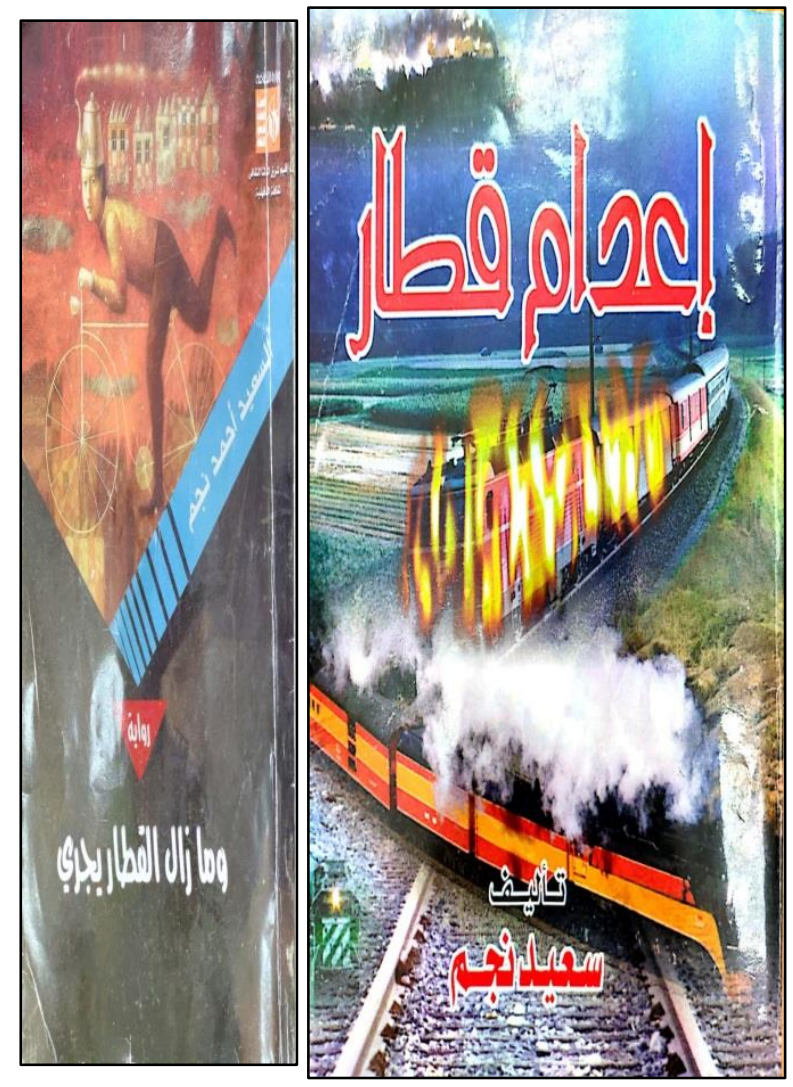

الغلاف هو أول شيء قد تقع عليه عينا المتلقي، ومن تم فهو قد يجذبه إلى العمل الروائي، فيثير فيه نوعًا من الدوافع التي قد تدفعه لشراء هذا العمل وقراءته، وعلى العكس قد يكون 
الغلاف عاملاً من عوامل الطرد للمتلقي، فلا يثير فيه هذا الدافع للقراءة. ويرى البحث أنه في

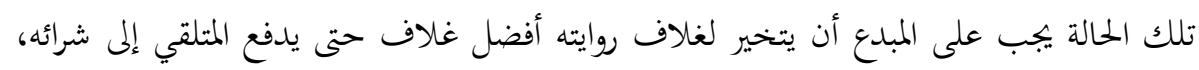

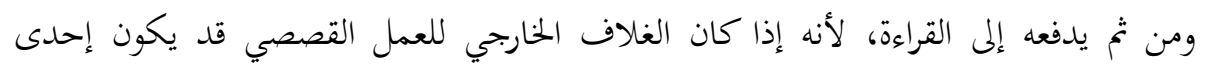

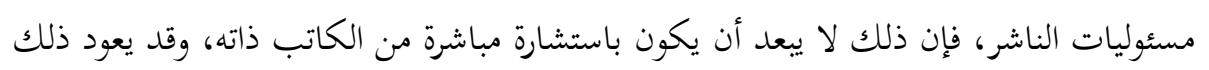

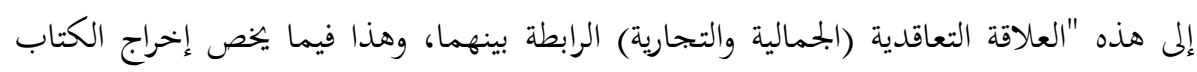

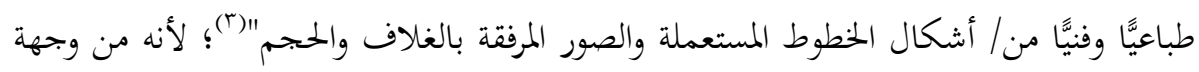

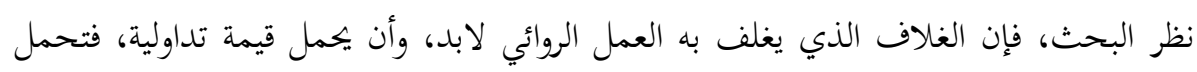

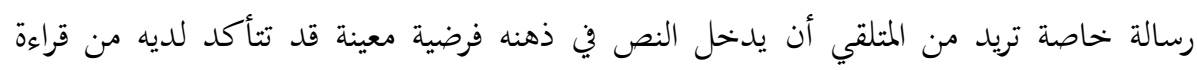

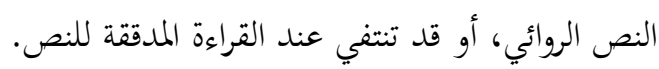

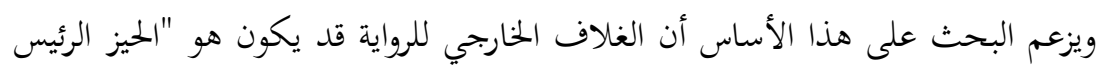

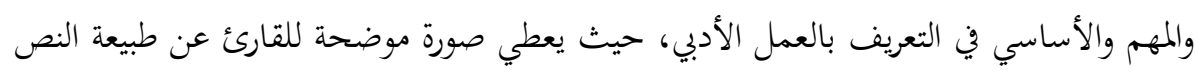

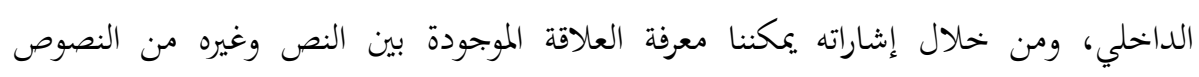

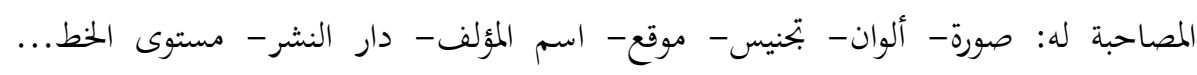
وغيرها. (๕)" (1) والسعيد بنم في روايتيه يقدم لنا غلافين يزعم البحث أنه اشترك فيهما مع الناشر في

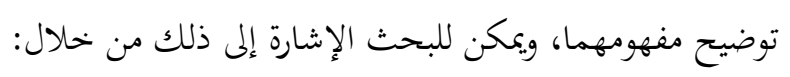

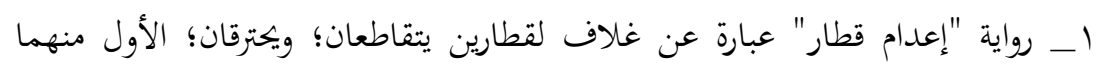
تظهر منه النار واضحة، والثاني لا يظهر إلا الدخان الذي ينبعث منه، واحتراق القطار قدار قدار يكون المقصود بها التعبير عن حالة الإعدام، وقد عبر عن هذه الحالة من الاحتراق والدخحان بانتشار

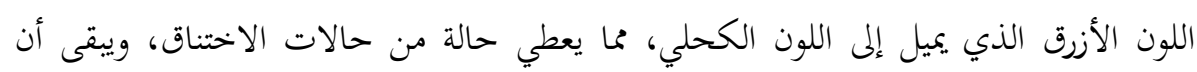

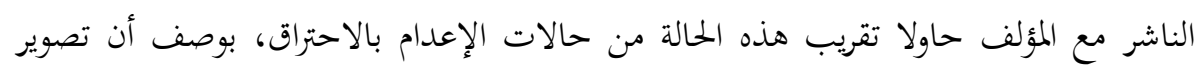
الإعدام بحبل يلف على مقدمة القطار قد لا يعطي للمتلقي المعنى المقصود.

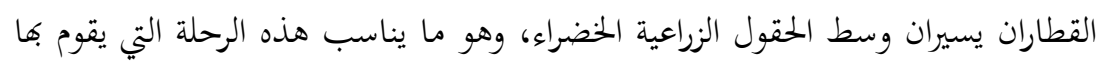

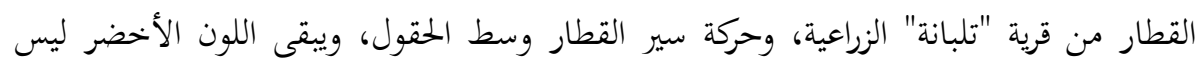

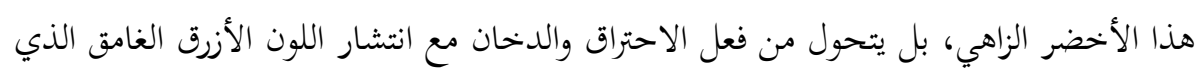
سبق توضيحه أن اللون الأخضر يتحول إلى اللون الرمادي. 
وكُتب العنوان باللون الأحمر ليناسب خاصية الإعدام، ووضعه الناشر في أعلى الغلاف

$$
\text { فوق صورة القطار المحترق، وبخط كبير ليجذب انتباه المتلقي. }
$$

كُتب اسم المؤلف باللون الأحمر القاتم، في أسفل الصفحة، وبخط صغير، وقد يكون اختلاف اللون بين العنوان واسم المؤلف لأن الناشر أراد من المتلقي ألا يمزج بين العنوان والمؤلف،

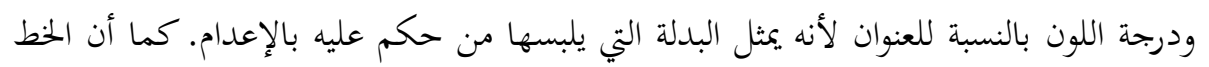

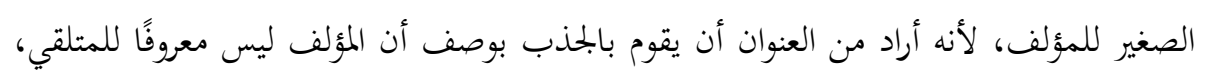
بل إن هذه الرواية تعد أولى أعماله، ومن هنا وجدناه يضع اسمه من اسمين فقط "سعيد بخم".

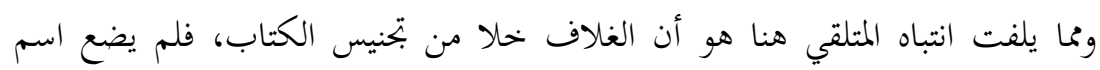
"رواية" عليه، ويزعم البحث أن الناشر هنا كان يبحث عن عامل الجذب للمتلقي بشكل عام؛ سواء أكان هذا المتلقي يهتم بعنصر الرواية أم لا يهتم به.

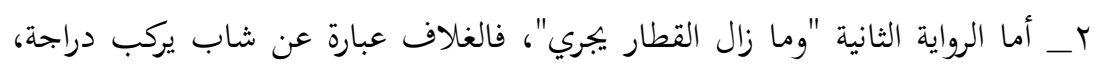
وعلى رأسه براد يخزج منه بخار، والشاب في وضع الاستعداد للحركة، وهو ينظر إلينا بتحفز، وهو

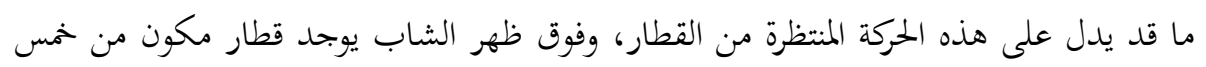

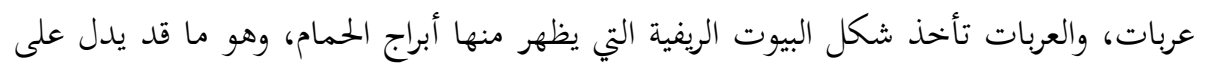
حركة الحياة الدائمة والثابتة من خلال البيوت، والمتجددة من خلال أبراج الحمام، ومن خلال عجل الدراجة الذي يضعه للبيوت مما يبعله يؤكد هذا التجدد للحياة. وُضعت هذه المكونات في خلفية من اللون البرتقالي، ويزعم البحث أن اختيار هذا اللون

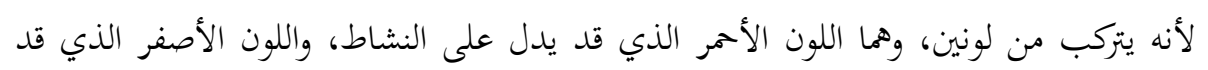
يبرز حالة من السعادة مع بعض الغيرة، ومن هنا فقد يدل اللون البرتقالي على مزيج من مشاعر الإثارة والحماس والدفء، ويزعم البحث أنه في تلك الحالة تناسب الصورة التي ؤضعت، فالإثارة والحماس تناسب هذا الشاب الذي يتأهب لركوب الدراجة، وحالة الدفء تناسب هذه البيوت الدالة على الاستقرار النفسي. على عكس عنوان رواية "إعدام قطار"، الذي وضع في أعلى الغلاف بنمط خط كبير،

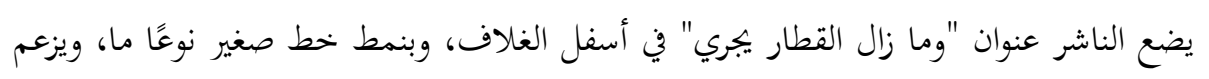
البحث أن السبب قد يعود إلى أن الناشر يريد جذب المتلقي إلى الصورة التي وضعها خلفية

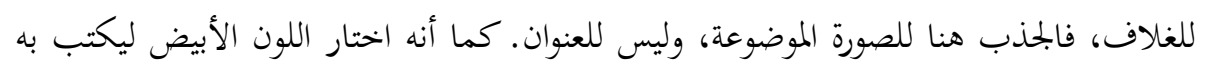
العنوان، وهو لون قد يحمل دلالات السعادة، بوصفه لون فستان الفرح. 
كتب الناشر اسم المؤلف ثلاثئَّا "السعيد أحمد بخم"، وأيضًا باللون الأبيض كما العنوان،

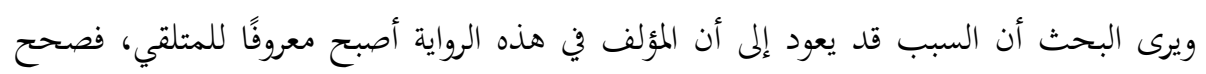

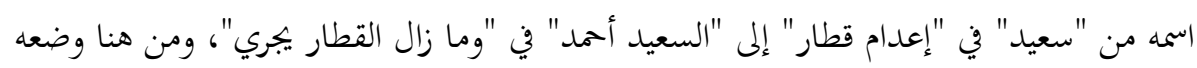
الناشر في وسط الغلاف على اليمين في خحلفية تحل اللون السماوي الدال على لون السماء

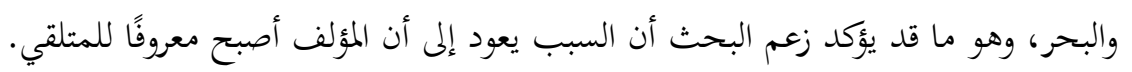

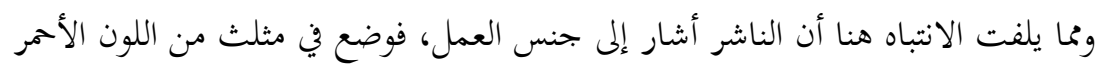

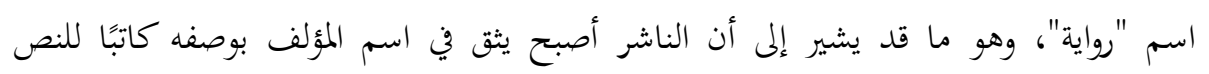
الروائي، وأنه مع التجنيس قد يجذب المتلقي لشراء العمل. وبهذا يكون الغلاف في الروايتين قد حمل قيمة جمالية تداولية، وهو ما قد يظهر من لئل خلال: 1_ اختيار الألوان، وقد ظهر أن اللون الأبرز في رواية "إعدام قطار" هو اللون الأحمر بما

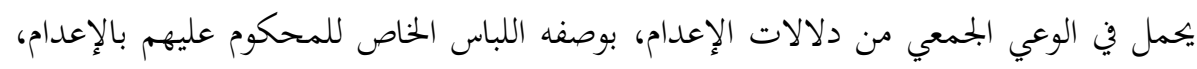

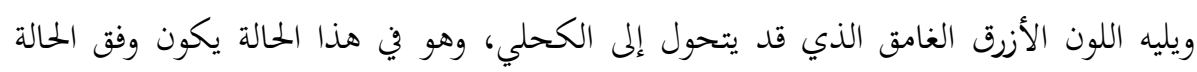
النفسية للمتلقي. ووضح أن اللون الأبرز في رواية "وما زال القطار يجري" هو اللون البرتقالي، بما يحمله من دلالات الإثارة والحماس والدفء. r_ استطاعت الصورة المرسومة إلى حد ما أن تبرز دلالات العنوان سواء في "إعدام قطار" أو "وما زال القطار يجري". r__ لعدم معرفة المتلقي بالمؤلف في رواية "إعدام قطار" اهتم الناشر بإبراز العنوان، ولم يهتم بإضافة جنس العمل، فأهمل كتابة "رواية" على الغلاف.

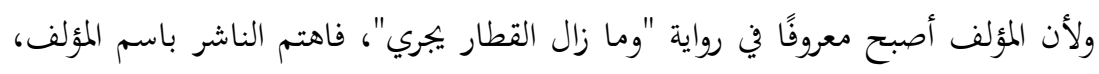

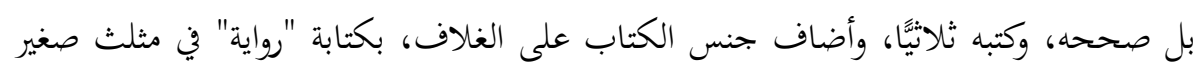

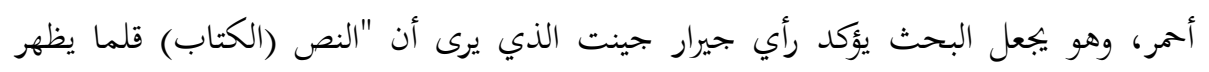

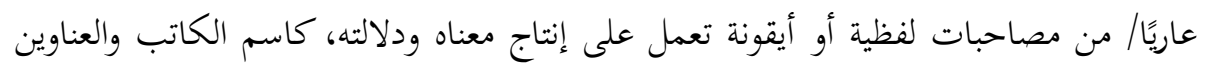

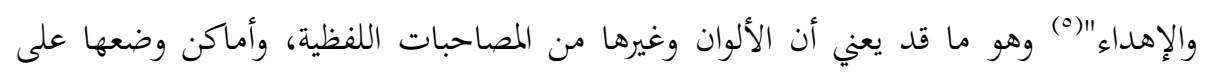

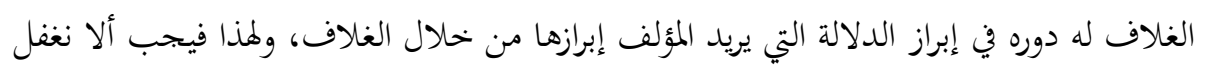


دور المؤلف في اختيار الغلاف لأن الغلاف لا يوضع اعتباطًا، بل لابد أن يكون دراسة متأنية ليتوافق مع العنوان والمضمون إن أمكن.

\section{ثانيًا: دلالة العنوان}

يهتم مؤلف العمل الروائي بعنوان عمله، وفي ذلك يحاول أن يضع لعمله العنوان المناسب العبان

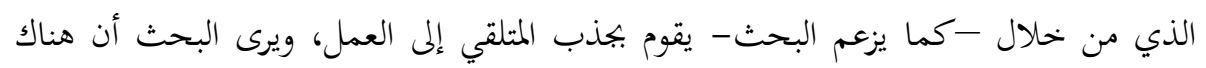

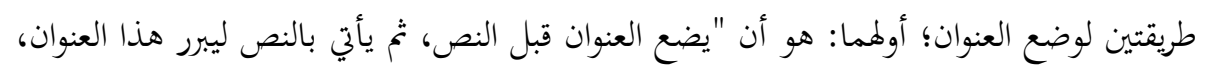

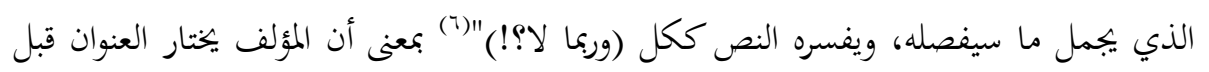

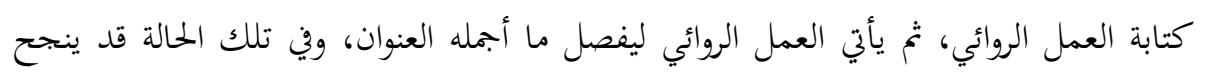
العمل في إبراز دلالة العنوان أو قد لا ينجح.

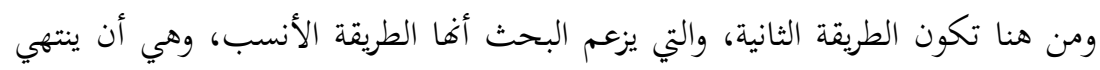

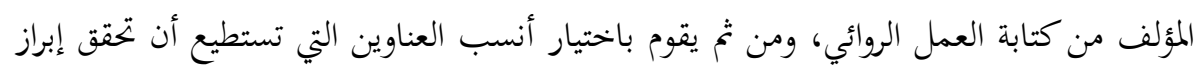

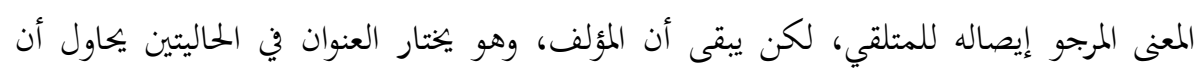

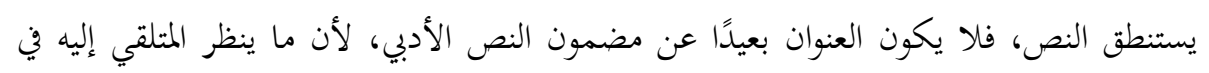

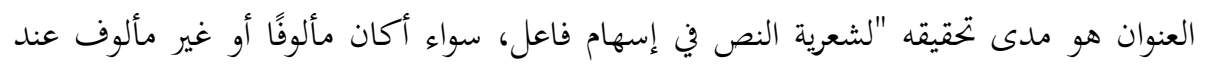

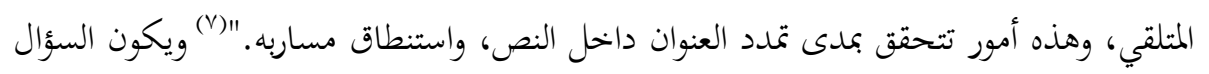

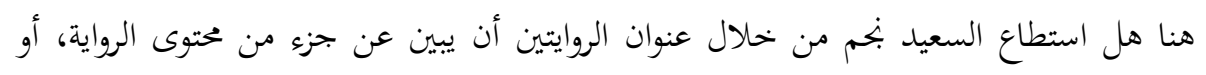

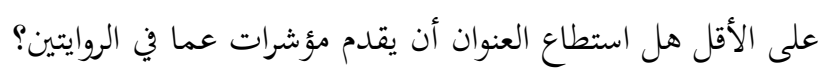

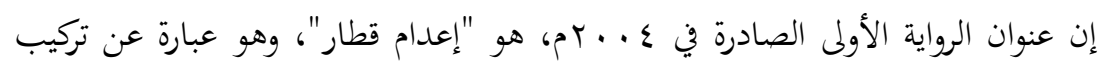

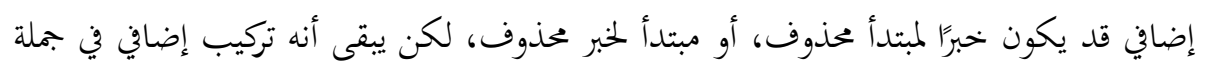

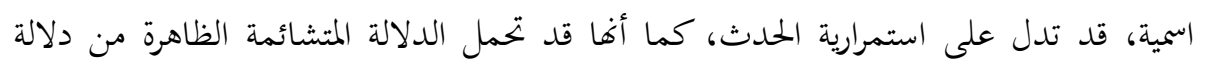

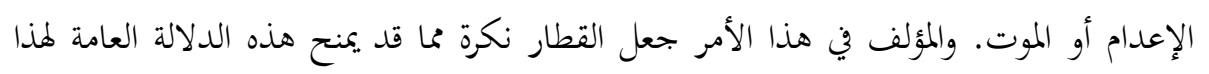
القطار.

كما أن دلالة الإعدام تحمل دلالة القصد من المهُعِدم، وهو نتيجة لحُرم قام به المُعْدَم، لكنه

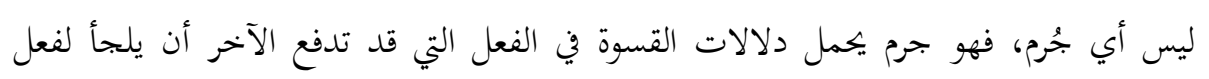
الإعدام. بينما يأتي عنوان الرواية الثانية الصادرة في عام ع ا ـ بم هو "وما زال القطار يجري"، فيحمل عدة دلالات؛ 
فأولاً: حرف العطف "و" الذي قد يدل على أن هناك معطوفًا عليه، وقد يعني أن هذه

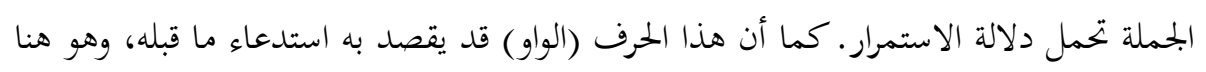

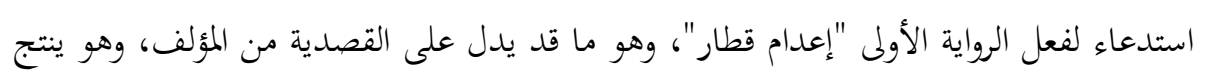

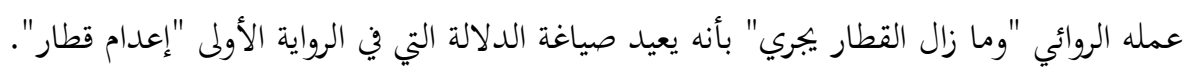

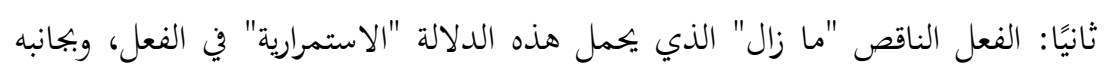

$$
\text { الفعل المضارع "يجري" الذي يؤكدها. }
$$

وبهذه الاستمرارية التي يؤكدها العنوان تحمل الرواية هذا المعنى المتفائل في أن القطار ما زال

يجري رغم أنه في الحقيقة التاريخية تم إزالته.

ثالثًا: تعريف "القطار" التي قد تشير إلى أنه يقصد قطارًا بعينه، وأن الدلالة ليست بعائه بعامة.

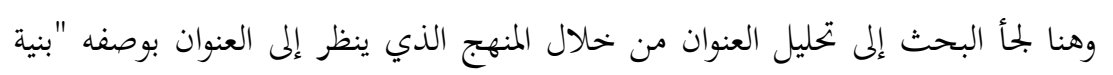

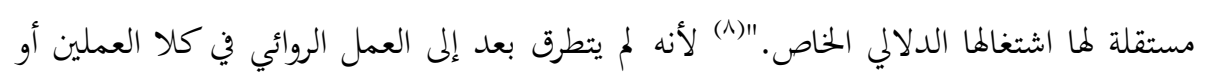

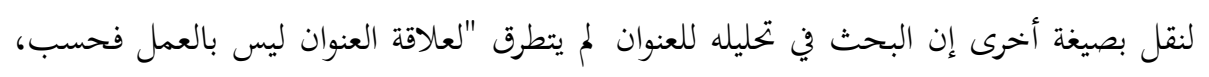

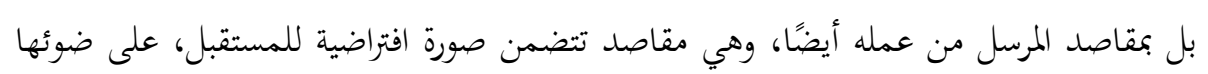

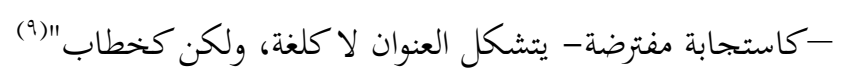

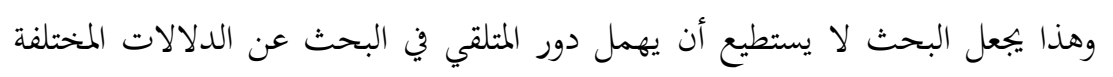

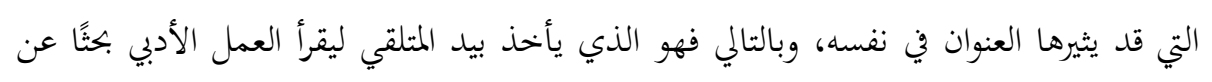

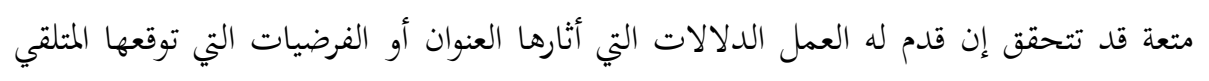

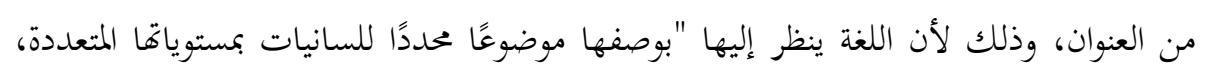

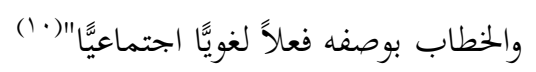

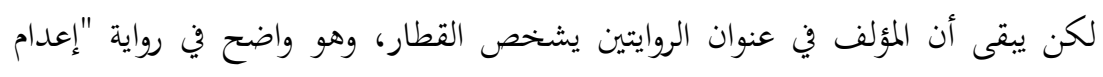
قطار"، بوصف أن الإعدام بشكل كبير يكون للإنسان، لكن وإن كان المعنى في "وما زال القطار

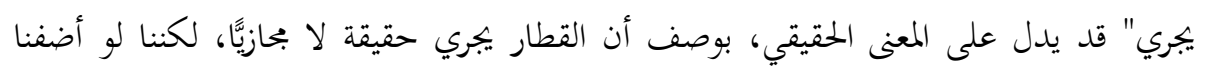

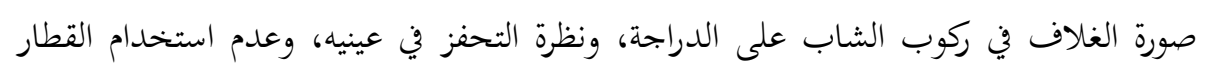
صراحة في الغلاف، فيزعم البحث أن المؤلف قد يريد هذا البعد التشخيصي في الرواية.

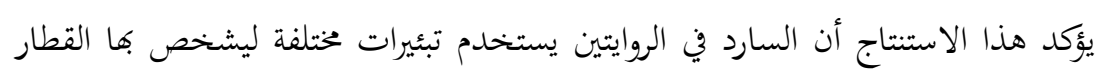
بوصفه الكلمة الوحيدة التي تكررت في العنوانين، ومن أمثلته في الروايتين: 
اــ يقول في رواية "إعدام قطار": "كانت هناك قضبان حديدية عليلة واضحة الضعف يسير عليها قطار عجيب أكثر ضعفًا واعتلالاً. يترنح عند المسير... كأنه ثمل، أو هاجمه نوم ثقيل (11)" غلاب. (11)

والمعنى نفسه يعرضه السارد في رواية "وما زال القطار يجري"، فيقول: "قضبان حديدية

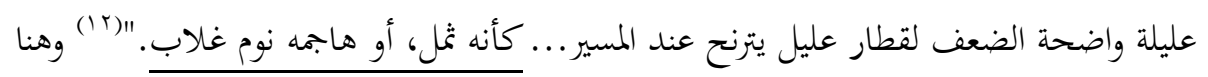
يشخص القطار، ويعطيه صفات الإنسان السكران (الثمل)، أو الإنسان الذي غلبه النوم الثقيل

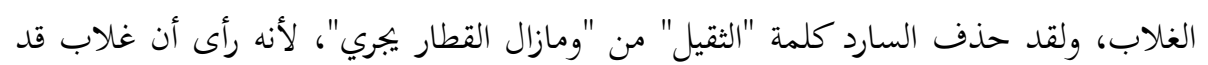
تفيد معنى الثقل مع القوة، وكل ذلك ليصور للمتلقي حالة الترنح التي يسير بها القطار.

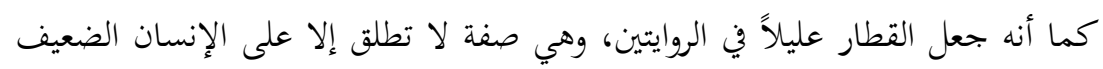
الذي يحمل ما لا يطيقه، ومن هنا فقد استبدل السارد "عجيب أكثر ضعفًا واعتلالاً" بكلمة إلمال

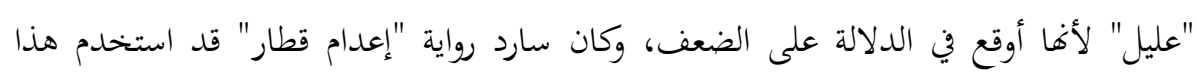
التعبير، فيقول: "هذا القطار العليل"("r)"، وهو ما قد يدل على أن سارد رواية "وما زال القطار "يجري" أفضل في التعبير عن حالة ضعف القطار، وعدم قدرته.

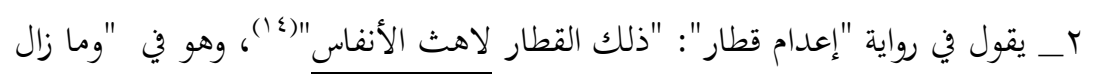
القطار يجري" بالصياغة نفسها، ويضيف إليها، فيقول: " ذلك القطار لاهث الأنفاس يتلوى بحمله الثقيل"(10)، و "لاهث الأنفاس" دلالة على هذا الضعف من القطار، وإضافة "يتلوى بحمله الثقيل" في "وما زال القطار يجري" تقوي من حالة الضعف التي في القطار، وتقوي من تشخيص القطار.

بـــــــ في "إعدام قطار" عن حركة القطار بعد أن امتلأ بالركاب: "القطار يبدأ مغادرته للصين متجهًا إلى المدينة كإنسان هاجمته خلية نحل شرسة، فبدا ككتلة نحلية ضخمة. القطار يبدو فعلاً ككتلة بشرية عجيبة الملامح من نسج غريب. الكل/ قد التحم بالكل والتصقت الأجساد مادئل بالأجساد والأنفاس بالأنفاس، وكادت أرواح تزهق!! يسير القطار ينوء بحمله، لاهث الأنفاس

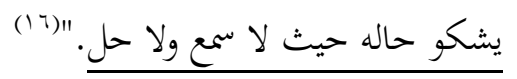

ويقدم سارد "وما زال القطار يجري" هذه الصورة بتصرف، فيقول: "يبدأ القطار مغادرته للصين متجهًا إلى المدينة، وقد اتخذ شكل كتلة بشرية فريدة من نسج عجيب. التحم الكل بالكل فرال والتصقت الأجساد بالأجساد وتلاحمت الأنفاس، يسير القطار يئن بحمله، وتصرخ القضبان. "IV) 
والفرق بين الروايتين هو استبدال الفعل "ينوء" المستخدم في "إعدام قطار"، والذي يبرز

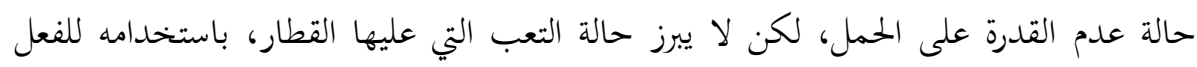

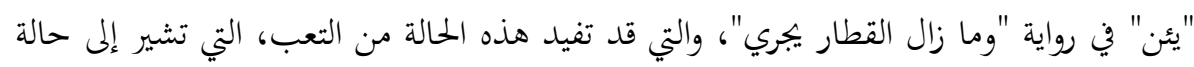

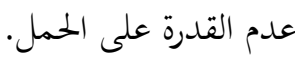

لكن سارد "وما زال القطار يجري" قام بحذف "لاهث الأنفاس يشكو حاله حيث لا سمع

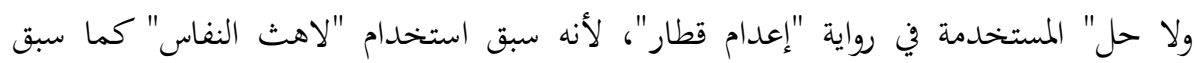
الإشارة.

أما عن "يشكو حاله حيث لا سمع ولا حل"، فلأنه يُفهم في وما زال القطار يجري من

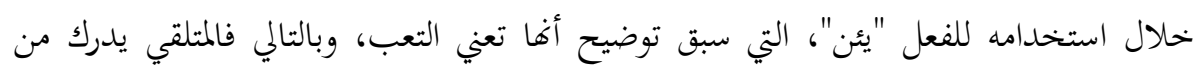
التعب هذه الشكو، ويدرك حالة اللامبالاة التي يعاني منها القطار.

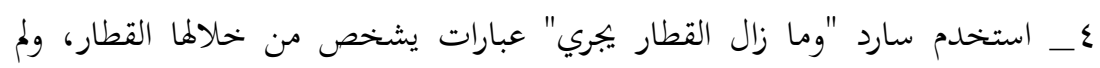
يستخدمها سارد "إعدام قطار"، ومن هذه العبارات: أ- قوله: "ينظر الفلاحون يحسدون راكبي القطار، ويمنون أنفسهم برحلة قريبة أو بعيدة.

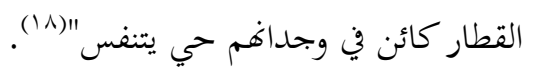
إنها رؤية فلاحي قرية تلبانة، ويصور السارد فيها أفم لا ينظرون إلى القطار بوصفه آلة

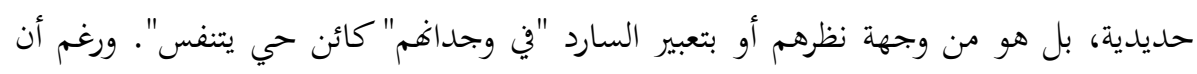

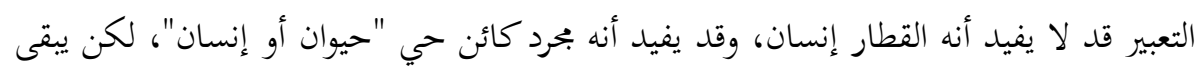

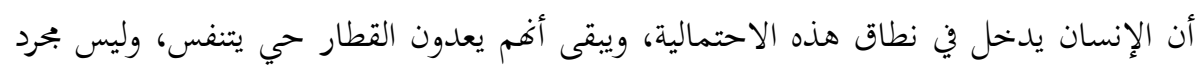
آلة، بمعنى أنه قد يتألم، وقد يفرح.

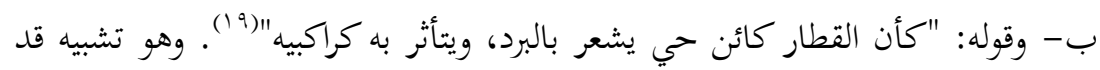

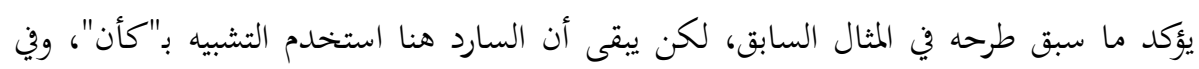

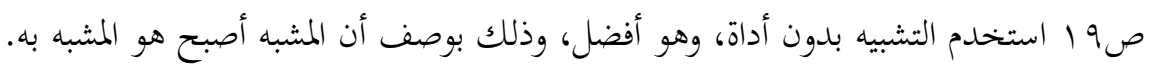

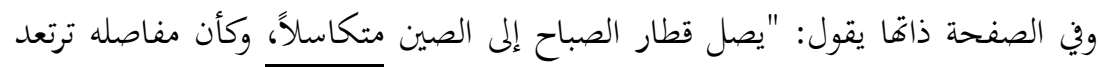

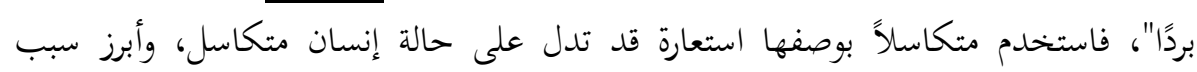

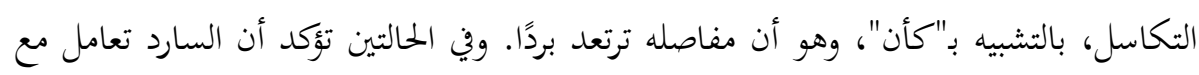
القطار بوصفه كائنًا حيَّا. 
هذا التشخيص للقطار قد يطرح رؤية أن القطار أصبح شخصية داخل الروايتين "إعدام قطار" و وما زال القطار يجري"، بل من الممكن أن يزعم البحث هنا أن البطولة الحقيقية في

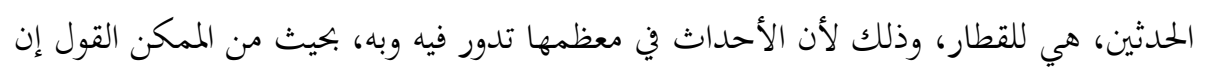
شخصيات العمل في الحدثين يرتبطون به، وهو ما سيظهر عند تحليل الشخصيات داخل الحدث الروائي.

\section{العنوان الفرعي وسنة الطباعة}

قد يلجأ المؤلف إلى وضع عنوان فرعي يكون شارحًا للعنوان الأساسي للعمل الروائي، وفي

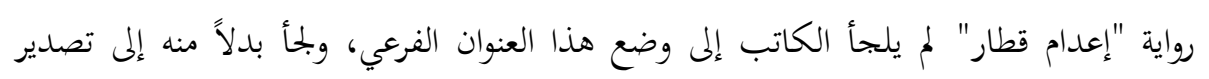

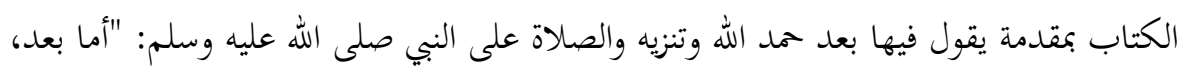
فإن هذه القصة الأدبية التي تحمل من المواعظ والعظات من الأعمال الأدبية الهامة التي

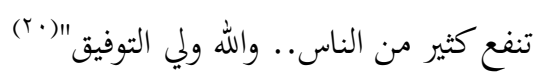

ما قد يشير إلى أن السعيد بخم، وهذا العمل الروائي يعد أول رواية له، ينظر إلى الأدب

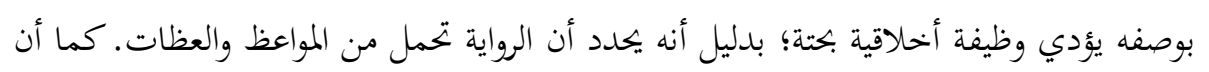

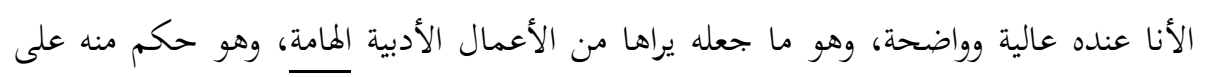

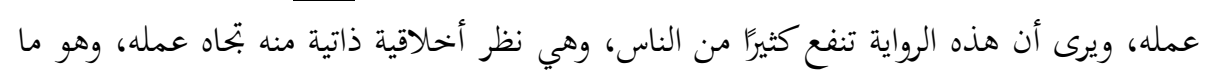
قد يؤهل القارئ إلى هذه الوظيفة التي وضحها له مؤلف العمل، لأن التصدير بهذه المقدمة قد

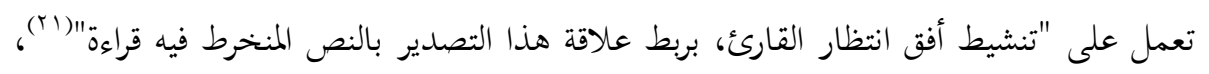
والنص هنا هو رواية "إعدام قطار" التي حكم عليها مؤلفها من خلال المقدمة، بأها تقدم مواعظ وعظات أو لنقل تقدم دلالات أخلاقية، ومن هنا فللبحث أن يتوقع أن القارئ سيبحث عن هذه

$$
\text { الدلالات الأخلاقية داخل هذا العمل الروائي. }
$$

أما عن رواية "وما زال القطار يجري"، فقد استغنى عن تلك المقدمة الأخلاقية، وهو ما قد مدرئ يوضح هذا التغيير في وظيفة الأدب عند هذا الأديب، فلم تعد الوظيفة الأخلاقية هي السمة الخاصة به.

ويزيّّ الروائي عنوان "وما زال القطار يجري" بـ"أسطورة عاشق"، مما قد يدل على أنه أراد إيصال رسالة إلى القارئ مفادها أن هذا العمل أسطورة خاصة به، وكونه عاشقًا يجعله قد يبالغ في بعض الأجزاء، بما أن المبالغة سمة العشاق في كل وقت ومكان. ويرى البحث أن هذا العنوان الفرعي الذي وضعه الروائي بعد العنوان الأصلي قد يقوم "بدور الوشاية/ والبوح، ومن شأن هذه 
الوظيفة أن تساعد في ضمان قراءة سليمة للكتاب، وفي غيابها قد تعتري قراءة المتن بعض هض

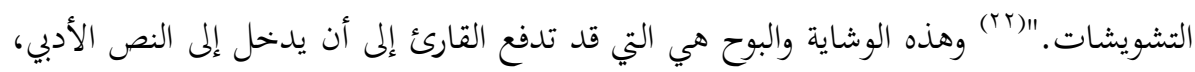
وفي ذهنه هذا المعنى من البحث عما يقدمه هذا العاشق من خلال هذه الأسطورة.

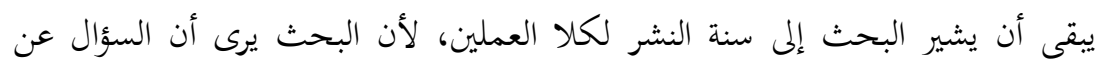

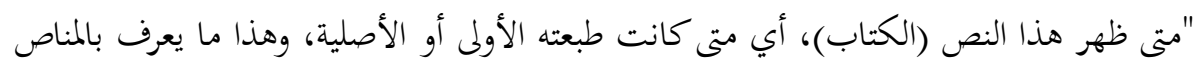

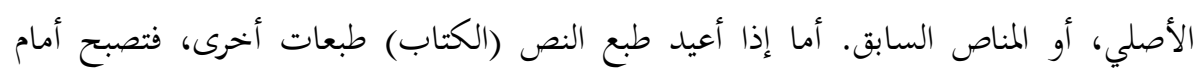

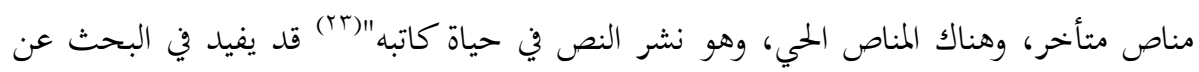

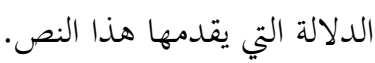

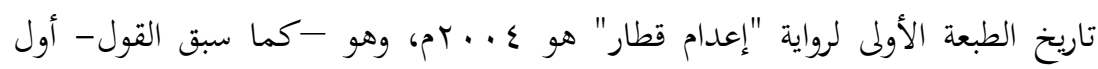
أعمال السعيد بخم الروائية.

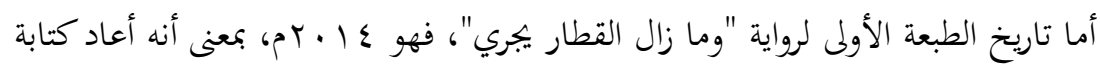

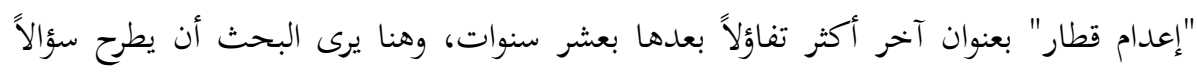

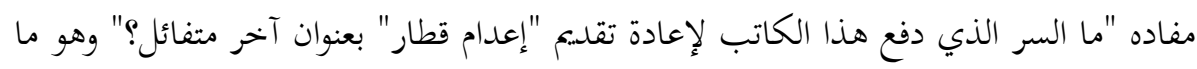

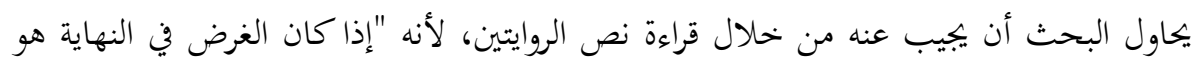

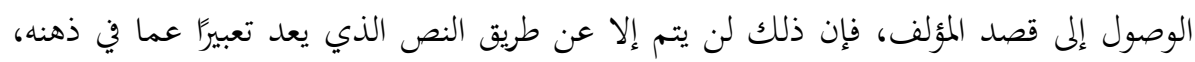

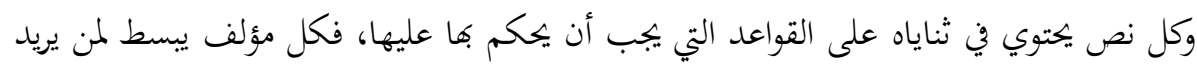

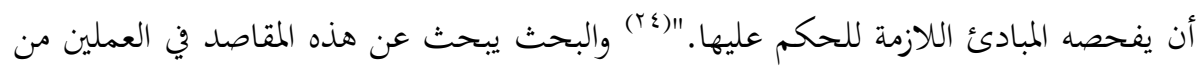
خلال دارسة (الاستهلال- الشخصيات- النهاية). إ_ـ الاستهلال

الاستهلال هو أول ما يطالعه القارئ في أي سرد روائي بعد الغلاف والعنوان، ويحاول المؤلف من خلال هذا الاستهلال أن يحقق عنصري التشويق والإثار التي تجعل القارئ يكمل بهما

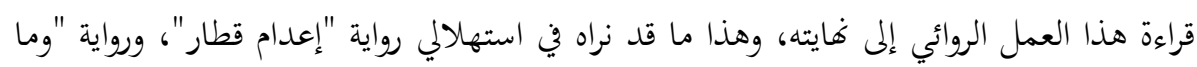

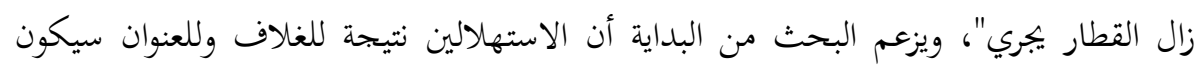
بينهما نقاط تماس واختلاف. يبدأ استهلال رواية "إعدام قطار"، بوصف عام لقرية مصرية. هذا الوصف قد ينطبق

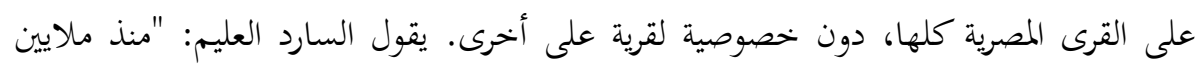

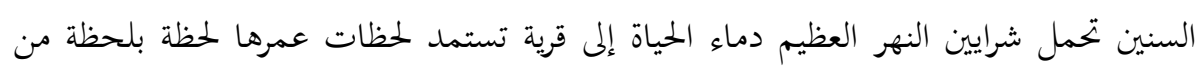




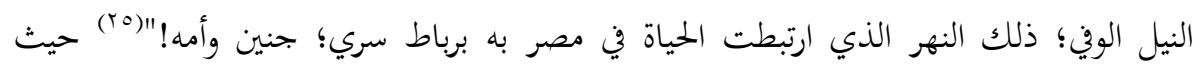

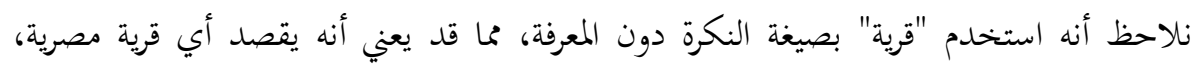
وليست قرية بعينها، وهو مشهد يبرز كذلك أن هذه القرية تقع على غر النيل الذي يصفه بالنيل الوفي، ويوضح سبب هذا الوصف باستخدام الاستعارة، وهذا الارتباط بين القرى المصرية وهذا النهر برباط سري، فهذا النهر هو الأم، والقرى هي أبناؤه.

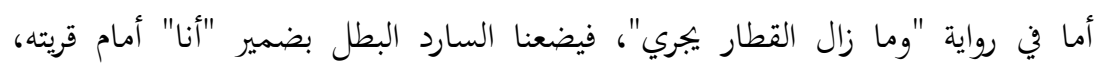

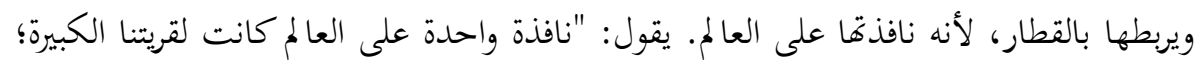

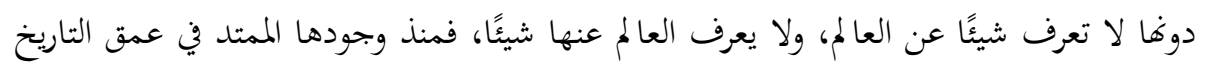

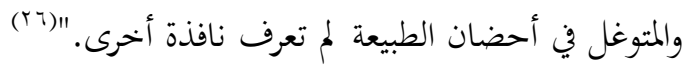
فقدم السارد بهذا السرد الواصف ارتباط القرية بالقطار، وقدم لكبر القرية، ولتاريخها، وقدم

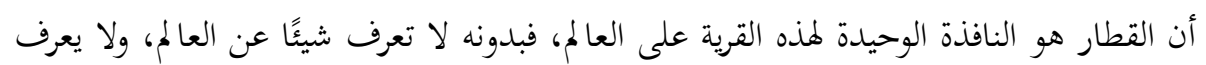

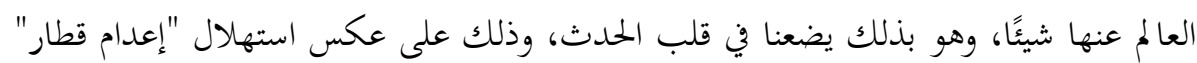
الذي لم يضعنا في قلب الحدث، وتركنا نبحث عن خصوصية القرية التي يريد السارد أن نتعرفها.

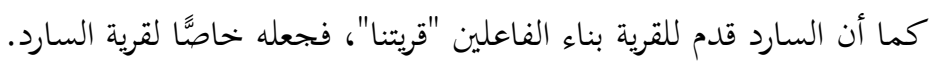
ونلاحظ هنا هذا التركيب الوصفي "نافذة واحدة"، فجعل منفذ القرية الوحيد على العالم

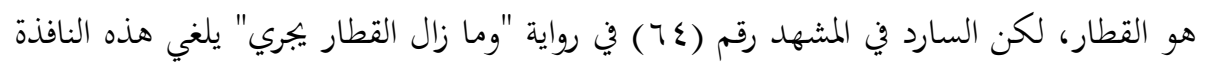

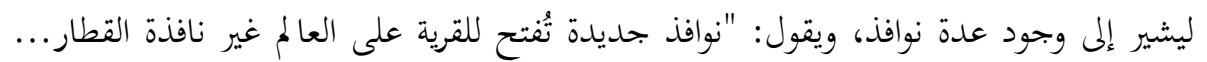

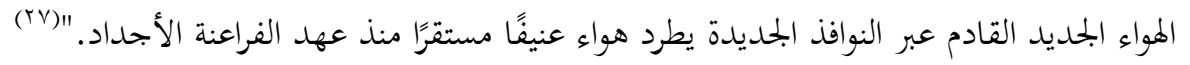

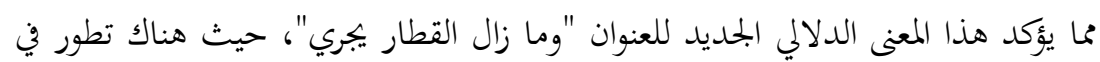

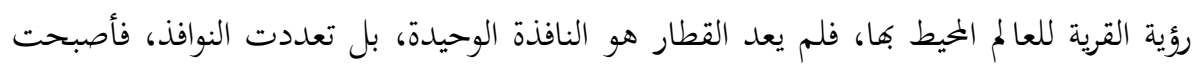
بذلك طرق المعرفة متعددة، بتعدد النوافذ التي تطل بها القرية على العالم.

\section{Y_ الشخصيات}

الشخصية في العمل الروائي هي التي قد تحمل الدلالة، وهي التي تدور بها الأحداث، إنها

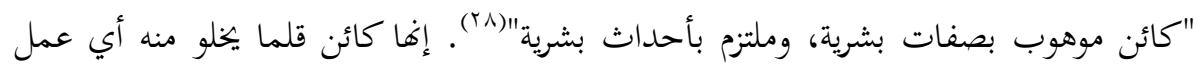

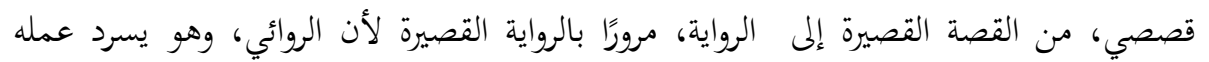

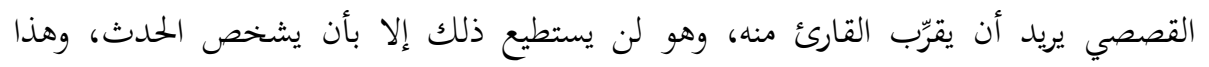

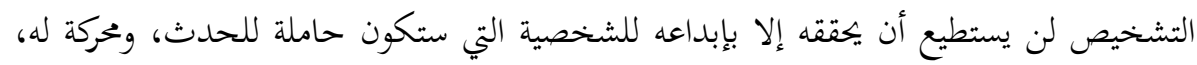


حتى وصل الأمر عند ناقدين مثل توماشيفسكي، ورولان بارت، وهما من نقاد البنيوية إلى الإقرار

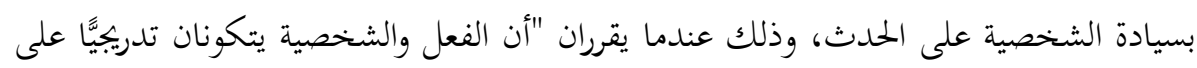

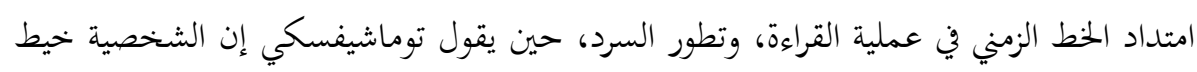

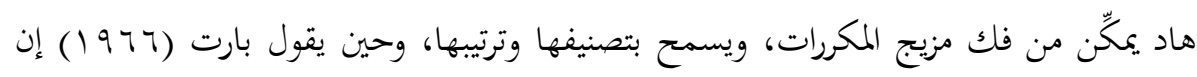

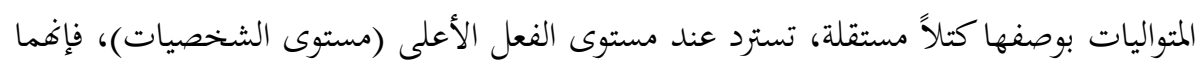

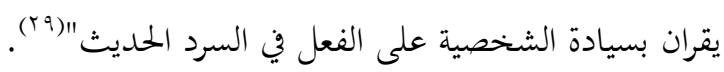
وذلك لأنه من خلال الشخصية - كما هو واضح- يتم التعرف على حركة السرد، فكما

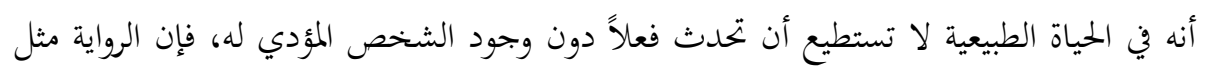

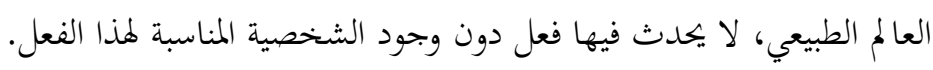

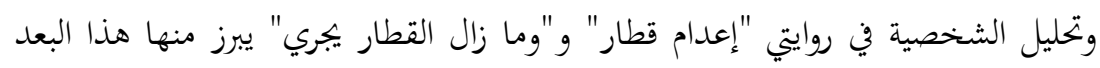

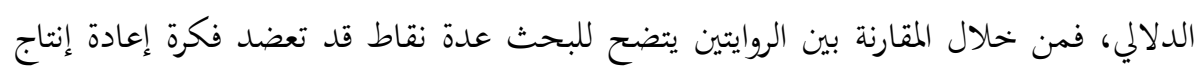
الدلالة بتغيير العنوان بين العملين، وبياها كالتالي: بالي:

\section{r-1 الشخصية الرئيسة}

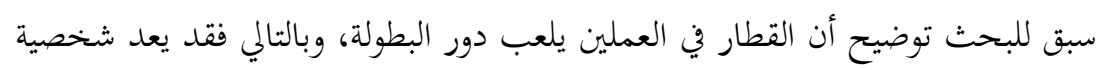

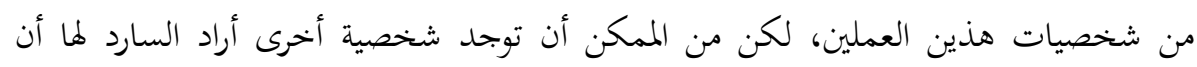

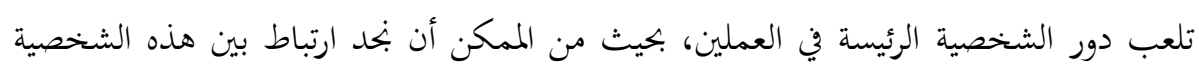

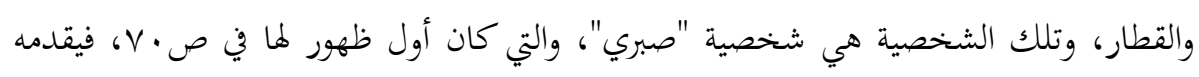

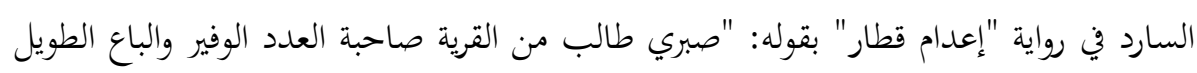
في المشاغبات التي تحدث في القطار. مفتول الساعدين. عريض الكتفين. منتفخ الصدر والرقبة. ضخم الكفين. ملامحه رياضية. واضح العنفوان."

وهو التقديم ذاته الذي يقدمه في وما زال القطار يجري، وبالكلمات ذاتها، فلا يزيد عليها،

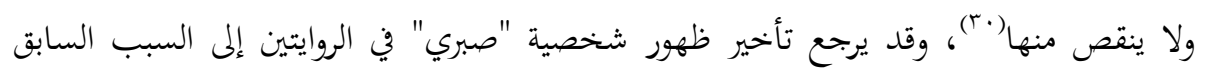
توضيحه، وهو أن السارد يعد القطار في الروايتين هو البطل الحقيقي لهذا الحلدث.

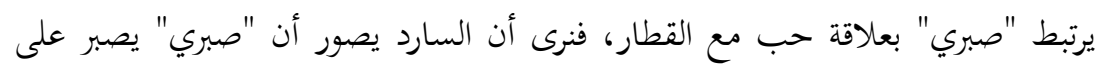

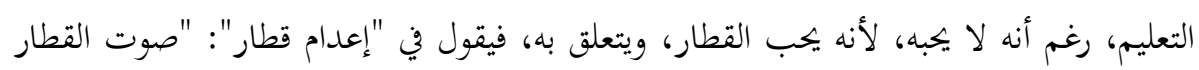

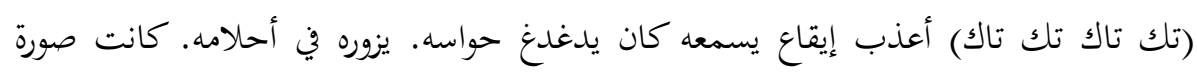


القضبان مع أعمدة التليفونات الخشبية بأسلاكها المتعددة التي توازي القضبان أجمل صورة لمنظر

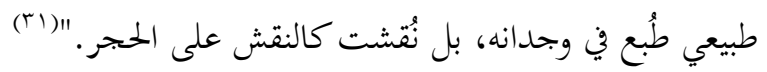
والمعنى نفسه يعرضه في صجء في "وما زال القطار يجري"، فيقول: "أعذب إيقاع يصل إلى أذنيه إيقاع القطار (تيك تاك تيك تاك)، إيقاع العجلات على القضبان. صورة القطار يجري على قضيبيه توازيه أعمدة التليفونات بأسلاكها المديدة وسط محيط مسطح أخضر على امتداد البصر أجمل صورة نقشت في وجدانه. لا تغيب."(rT)

والمعنى واحد تقريبًا بين المشهدين رغم اختلاف الصياغة بينهما، وإن أشار إلى أن صوت القطار يزوره في أحلامه في الإعدام ليصور من خلال هذه الصورة المحازية قوة ارتباط الشخصية بالقطار، وقد يعود حذف السارد لهذه الصورة من "وما زال القطار يجري"، لأفها قد تحمل نوعًا من المبالغة، وهو ما يريد البعد عنه.

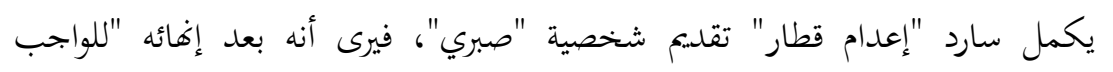
التجنيدي بحث عن عمل عن وظيفة. كانت سعادته حقيقية حين عُين مفتشًا في القطار الذي شهد أيام صباه، وشاركه أحلام طفولته. "(rT) لكنه في "وما زال القطار يجري" يصور أنه بعد أن "أفهى خدمته العسكرية الإلزامية، فبدأ

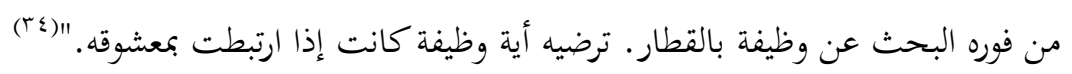
فجعل الوظيفة في القطار في "إعدام قطار" تأتيه صدفة، فلم يكن يريدها بعينها بل أراد أي وظيفة. ويف "وما زال القطار يجري" تأتيه برغبته، لأنه مَنْ بحث عنها، فأشار لبحثه "عن وظيفة بالقطار" دون غيره، ويرى أن أي وظيفة في القطار ترضيه ما دامت ستجعله يرتبط "بمعشوقه". وتركيب "بمعشوقه" قد يبرز إلى حد ما حالة الارتباط بين صبري والقطار، فهذه العلاقة وصلت إلى حد العشق التي بتعله يربط حياته به، وهي إضافة مقصودة من سارد "وما زال القطار يجري"، ولم يشر إليها سارد "إعدام قطار"، واكتفى بالإشارة إلى سعادته، وتوضيح أن القطار شهد أيام صباه، وشاركه أحلام طفولته، ومن هنا تكون حالة العشق التي عرضها في "وما زال القطار يجري"، وإن كانت فيها مبالغة، فإِها أوضحت مدى هذا الحب من صبري بتحاه القطار، وبالتالي أهَّل المتلقي أن يتوقع أي شيء من صبري بتحاه هذا القطار، لأن الكاتب في هذه اللحظة

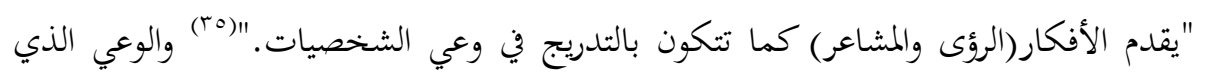


يريد الكاتب أن يوصله إلى المتلقي هي حالة العشق من "صبري"، بكل ما فيها من معان متناقضة.

عرض السارد في "إعدام قطار" أن أول عمل صبري في قطار كان "مفتشًا في القطار"،

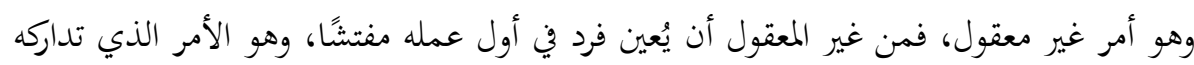

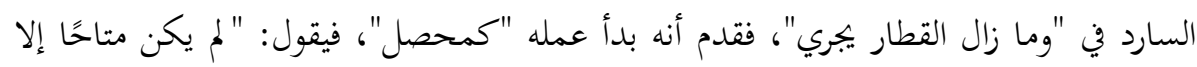
أن يعمل كمحصل"، وهو الأمر الطبيعي.

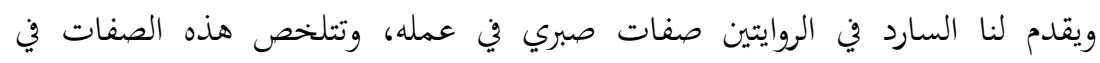

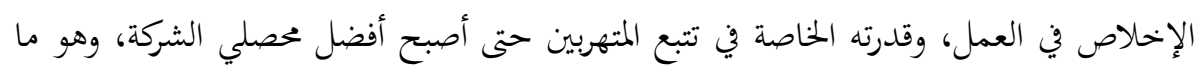

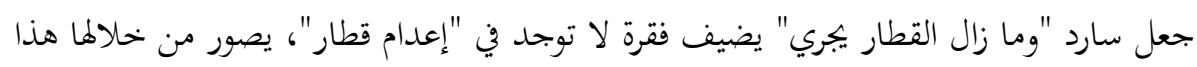

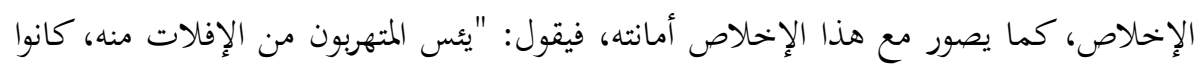

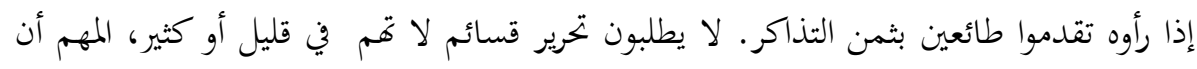
يتجاوزهم صبري، لكن صبري يصر بحسم على تخرير قسيمة بكل مبلغ يتلقاه. بعضهم يعطيه

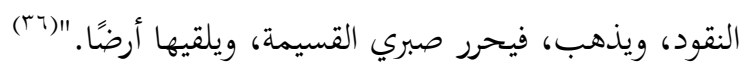

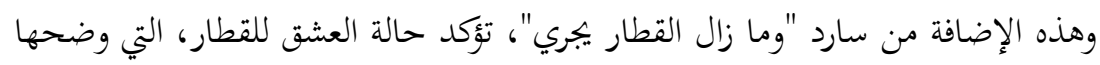
سابقًا. ويصور حبه للعمل الذي جعله يرى في العملين أنه "لولا أن النوم ضروري ما غادر الذرا

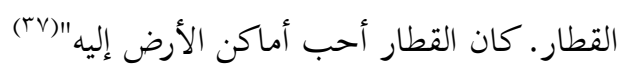
وهو الأمر الذي جعل صبري يشعر أن هناك علاقة متبادلة بينه وبين القطار، فيقول في الإرضه

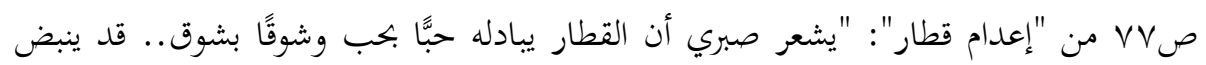
لآلة قلب بالحب!

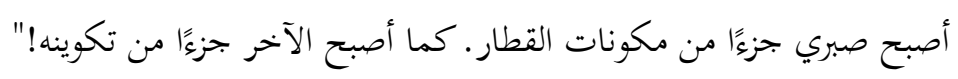

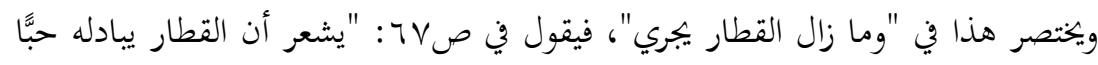
بحب، كأن له قلبًا سينبض.

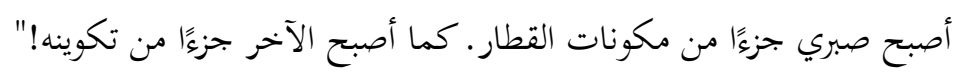

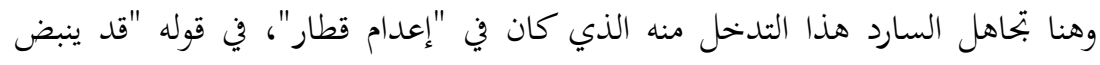

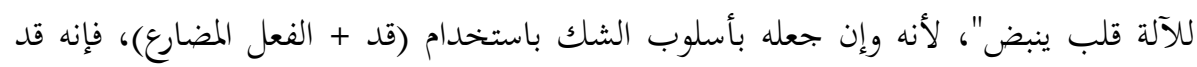

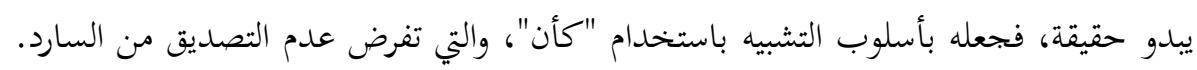


ورغم ذلك، فإن السارد أراد أن يتغاضى عن معنى أن يكون القطار "آلة"، فهو يريد ما سبق طرحه من أن القطار إنسان، وله قلب ينبض، وإن جعله تشبيهًا بكأن. لكن ما زال سارد حدث "وما زال القطار يجري" يضيف نقاطًا أخرى في شخصية صبري لم يذكرها في "إعدام قطار"، ليؤكد بها هذه الحالة من العشق من صبري، فيشير إلى نشاطه، وفكره الجديد في القضاء على ترب الركاب من تحصيل تذاكر القطار، فيقدم السارد أنه قسم القطار "إلى نصفين؛ نصف يفرزه صبري، والآخر لرفيقه. لكن صبري يعتبر نفسه المحصل الوحيد،

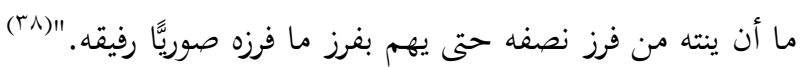
وهي إضافة قد تدل بجانب نشاط صبري، وقدرته على ضبط المتهربين من تحصيل التذاكر، على هذا الحب للقطار، وغيرته عليه، وخوفه من أن يركبه أحد دون دفع أجرته، وهو الأمر الذي جعل سارد "وما زال القطار يجري" يضيف في ص. . 1 ما يفيد هذا الخوف على ولى القطار، فنرى أن "صبري" حتى عندما يصبح ناظر المططة، وتكون مهمته أن "يبيع التذاكر، ويستخرج الاشتراكات الشهرية للركاب، ويستقبل ويرسل معلومات عن القطار من وإلى المطات التالية والسابقة." وقد يعني هذا أن عمله أصبح روتينيًا، وبعيدًا عن القطار -هذا المعشوق-، لكن هذا العمل الروتيني لصبري "لا يطفئ شوقه لمعشوقه الذي يجري حبه في دمه"، وهو ما جعل السارد يصور هذا العشق من صبري للقطار، فيراه: "ما إن يقف القطار بمحطة القرية الكبيرة حتى يهرع إليه صبري يدور حوله دورة كاملة، فيسلم على السائق، وما به من محصلين يسألهم إن كانت لديهم مشكلة أو يحتاجون لأية مساعدة، وكأن القطار ملكية خاصة به." هذا الجزء الأخير الذي ظلل يصور لنا هذا المنظور من الشخصية الرئيسة "صبري"، فهو ملهو كما يضيف السارد لحدث "وما زال القطار يجري" لا ينظر إلى نفسه بوصفه موظفًا في القطار،

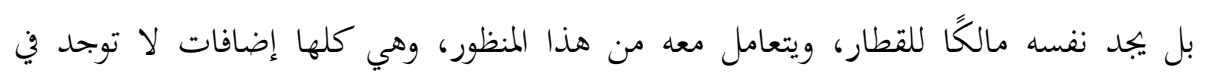
"إعدام قطار"، ومن هنا تكون هذه الإضافة قد استطاعت أن تؤكد هذا الارتباط بين شخصية صبري والقطار بوصفه شخصية روائية، وهو ما سيظهر عندما يعرض البحث لشخصية "منعم" التي أضافها سارد "وما زال القطار يجري"، وهي الشخصية التي لا توجد في رواية "إعدام قطار". 


\section{r r r إضافات في رواية "وما زال القطار يجري":}

يقصد البحث هنا أن السارد في رواية "وما زال القطار يجري" أضاف شخصيات وأحداث إلى الحدث في الرواية لم تكن موجودة في رواية "إعدام قطار"، ويزعم البحث أن هذه الإضافات قد تعمق من دلالة العنوان المتفائلة.

\section{r-Y - إضافة شخصية "منعم":}

تعد شخصية "منعم" شخصية ثانوية في رواية "وما زال القطار يجري"، ويزعم البحث أها تقوم بوظيفة "إعادة تقديم التجارب المنوطة بالشخصيات الأساسية في الرواية، وعندما تعيش الشخصيات الثانوية نفس المواقف الشعورية باعتبارها شخصية رئيسة، أو تشارك في موقف يوازي موقف الشخصية؛ فإها تؤدي وظيفة النظير"(ج") وهذا الدور تقوم به شخصية "منعم" إذا قورنت بشخصية "صبري" الشخصية الرئيسة، والسابق عرضها، فنجد عدة ملاحظات في طرق تقديم

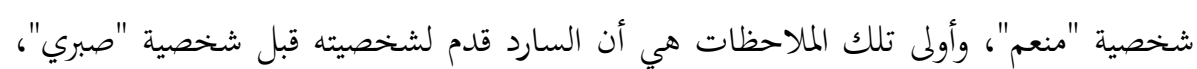
وذلك لأغها الشخصية الأكثر إيجابية من شخصية صبري السلبية، وهو ما قد يبرز أن السارد يرغب في الإيجابية في مواجهة العقبات التي نواجها، ويريد سيكولوجيَّا أن يوصل هذه الرسالة إلى المتلقي فلقد اختزل بروب وظيفة الشخصية "إلى نمذجة بسيطة تقوم على أساس وحدة الأفعال

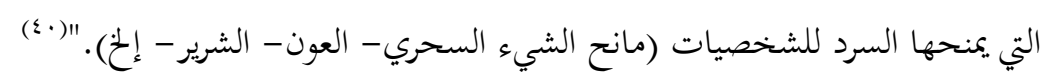
فيبدأ السارد بتقديم وصف للهيئة الجسمانية لمنعم، فيقول: "طويل عريض مهيب البناء

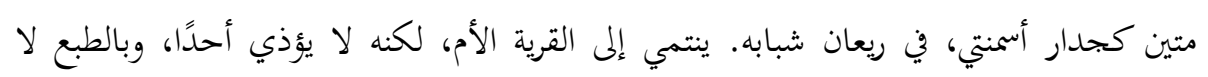
يؤذيه أحد، لكنه لا يمنع إيذاءً. "(1) هذا الوصف للبنية الجسدية، التي تجعله مهيبًا، -والتي توازي الوصف الجسدي لشخصية

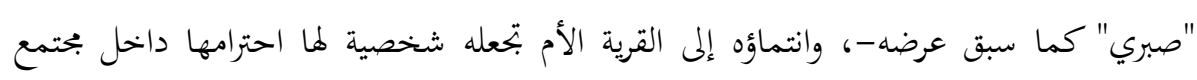
القرية، لكنه في البداية تبدو شخصية سلبية في عدم منع الإيذاء عن الآخرين.

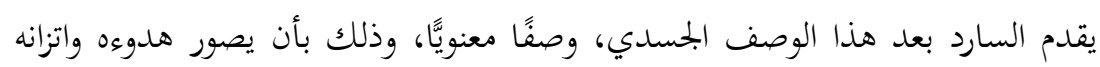
حتى، وهو يشترك في الحوارات مع بحتمع القطار، فيقول: "قد يشترك في حوارات أو مناقشات

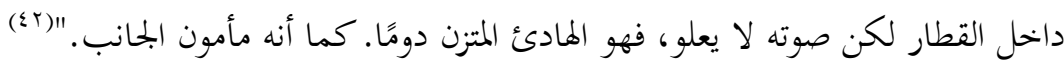

ويكمل السارد هذه الطباع، فيصور خجله عندما تغازله شهيرة (بائعة الدواجن)، فيكون رد فعله هو أن "يتوارى خجالا، ولا يعقب. 
ويصور احترامه لنفسه، وترفعه عن معاكسات الفتيات، فيشير إلى أنه "لم يُر في وضع حرج خلف أنثى. مشهود له بالخلق الرفيع." لكنه يصور بعد ذلك إعجابه بإحدى الطالبات التي تنتمي إلى قرية تقع بعد القرية الأم،

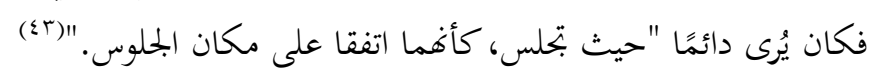
ويكون هذا الإعجاب هو الشرارة التي تغير من سلبية "منعم" التي سبق عرضها، وهذه

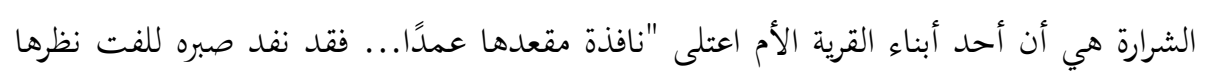

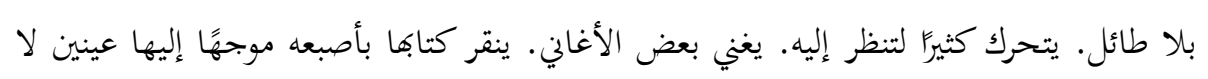
ترمشان، فتنشغل عنه." هذا المشهر يرقبه "منعم"، لكنه يسيطر على انفعالاته إلى أن "يقتنص

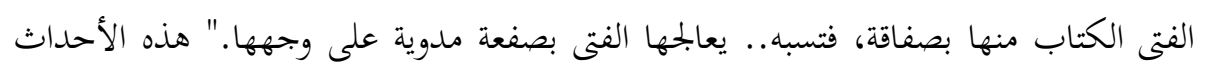

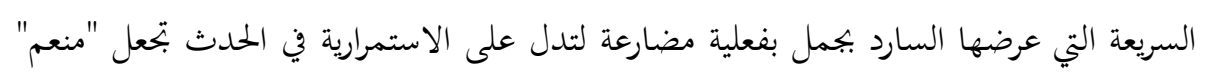
ينتفض، "ويهجم على الفتى كعاصفة، فيسحبه إلى غر العربة، وينهال عليه لكمًا وصفعًا، فاهمار

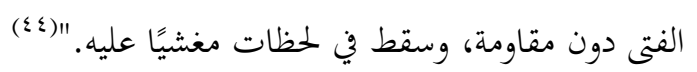

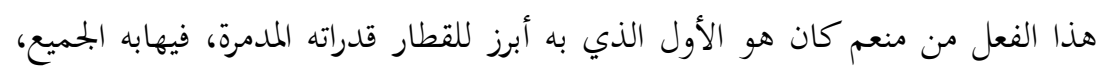

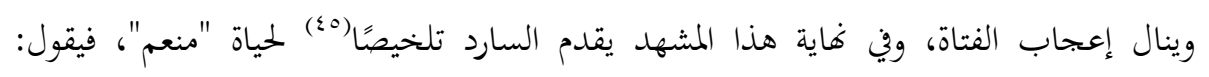
"شهد القطار منعم دارسًا ثم موظفًا في بداية حياته العملية، فخطيبًا لتلك الفتاة، فزوجًا لها، لكنه

$$
\text { لم يشهد له ثورة أخرى كهذه". }
$$

تغيب شخصية "منعم" عن الحدث الروائي لرواية "وما زال القطار يجري"، وتعود في لهوري صی ا ا ليقدم السارد نقطة جديدة في حياته، وفيها يعرض لعودته من الخارج بعد عامين، ويصور تقابله مع صبري، فيوضح "تغيَّ منعم كثيرًا.. آثنار التنعم جلية على وجهه؛ جلد مصقول ناعم. زاد نضارة على نضارته، وقوة على قوته، وانفكت عقدة لسانه. يتكلم كثيرًا، وقد كان

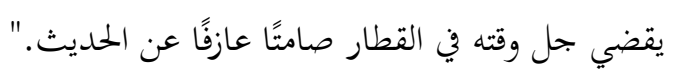
وهو ما قد يعني هذا التحول في الشخصية على المستوى الجسدي، وعلى المستوى

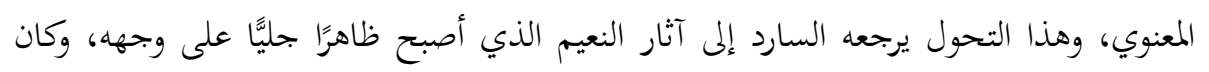
السارد في رواية "إعدام قطار"، قد أوضح أن هناك رياحًا "جديدة تَب على مصر بأكملها. رياحًا تحاول إزالة طبقات وطبقات من تراب تكونت عبر آلاف السنين على الوجه/ الجميل. نوافذ على العالم كانت مغلقة تفتح الواحدة تلو الأخرى ليداعب النسيم... اكتشاف البترول

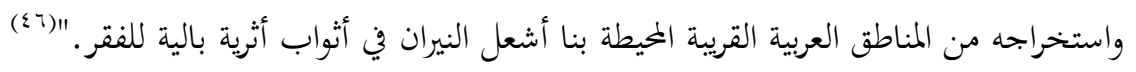


وهو الأمر الذي عرضه في "وما زال القطار يجري"، عندما أشار إلى أن هناك "نوافذ

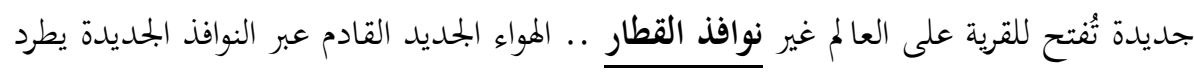

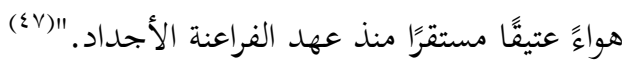
هنا يسترجع السارد هذه النافذة التي كان قد أشار إليها في أول جملة من الرواية عندما

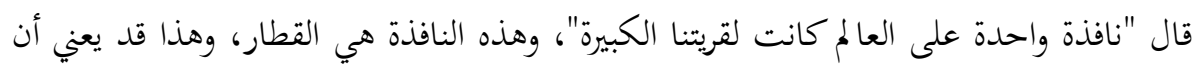

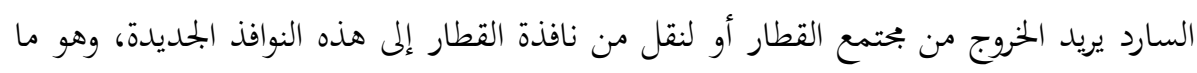

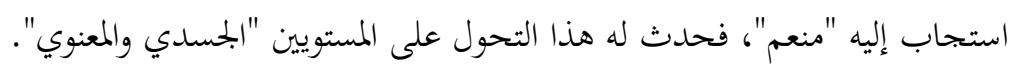

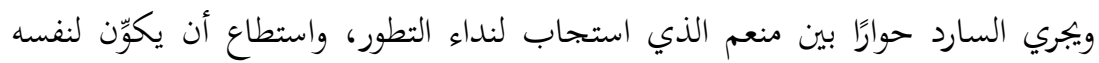

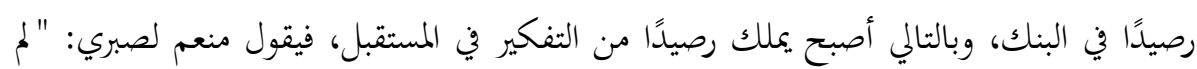

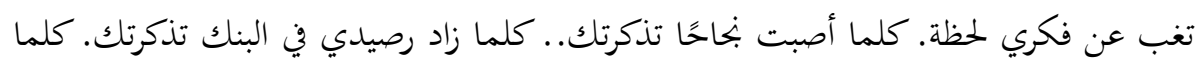

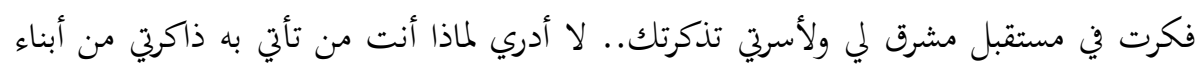

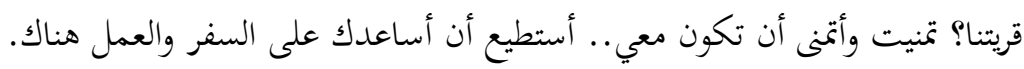

$$
\text { - يعني عايزني أسيب الشغل. }
$$

- هوه دا شغل.. دي سخرة يا صبري. - أنا مش قليل الأصل عشان أسيب الشركة دي الوقت. دئ.

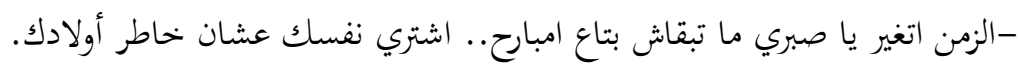

$$
\begin{aligned}
& \text { - إحنا عايشين والحمد لله. } \\
& \text {-بتسمي دي عيشة! } \\
& \text { - بتكرهني في عيشتي! }
\end{aligned}
$$

- أنا عايزك تعيش.. تعيش بجد فوق يا صبري الواد ابن ستيتة العربجي اللي كان مش لاقي

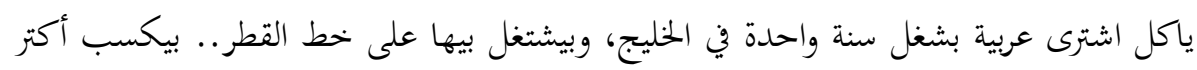
م القطر بتاعك.

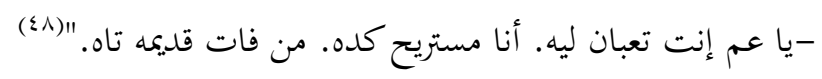

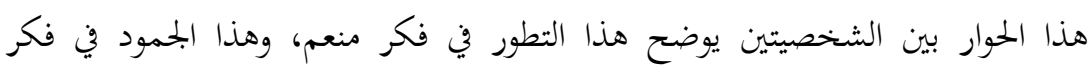

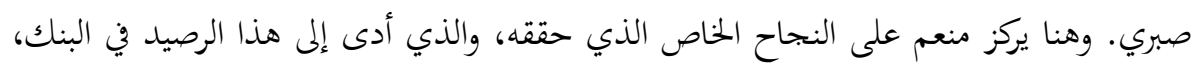

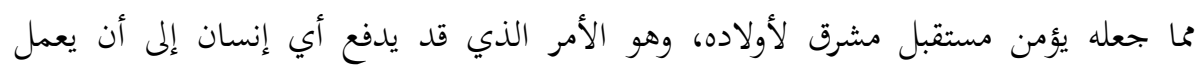

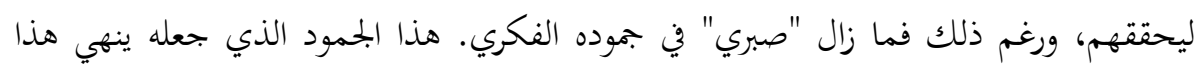


الحوار بالجملة التي يقولها هؤلاء الفشلة عديمو الحيلة "من فات قديمه تاه"، بالرغم من أن منعم

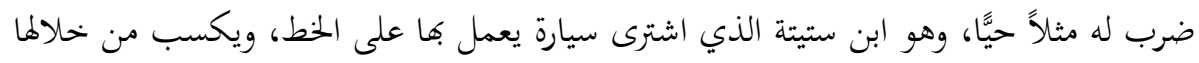

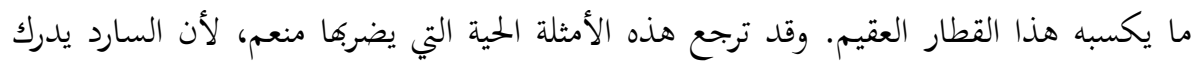

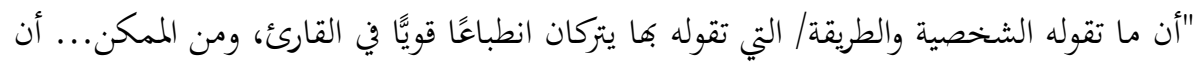

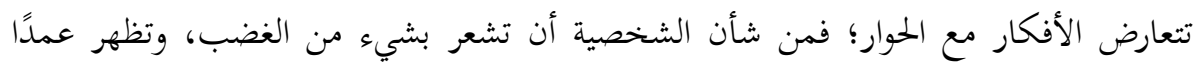

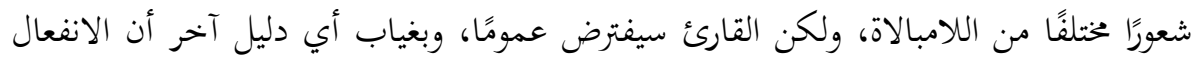

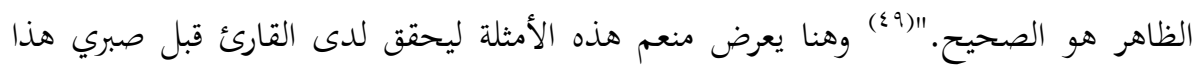
الانفعال الذي قد يؤدي إلى أن يواكب حركة التطور في العالم.

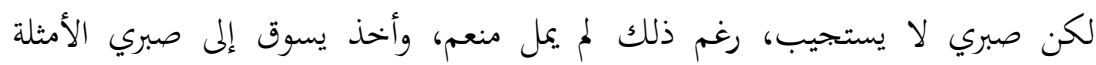

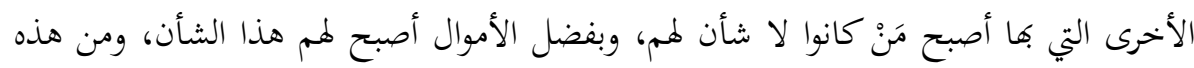
الأمثلة -وهو من الأحداث المضافة في حدث وما زال القطار يجري- "عبد الباسط (الزرافة) طويل الرقبة الذي هام بماجدة السمينة يغني لها بالقطار أغاني العندليب، وهي تستخفهات وتهات وتسخر

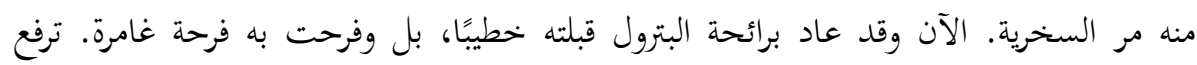

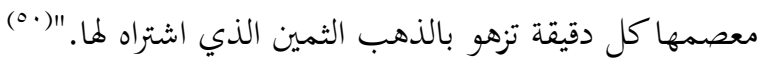

ويشير السارد إلى أن هناك الكثيرين الذي حكى عنى عنهم منعم حكايتهم، وما آل إليه

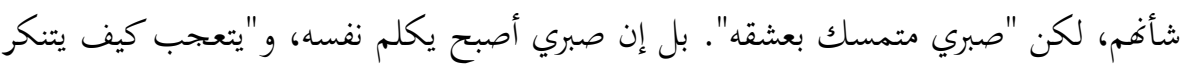

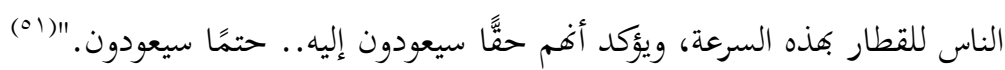

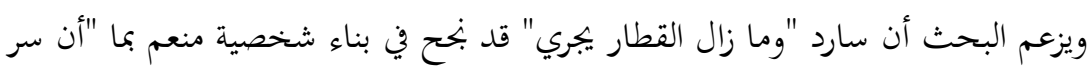

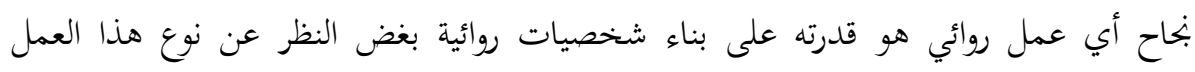

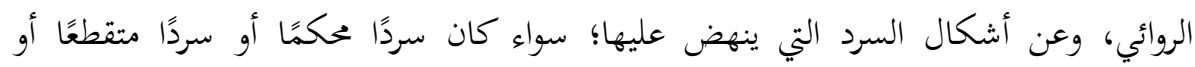

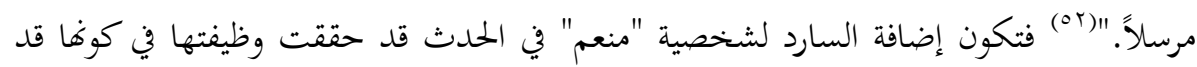

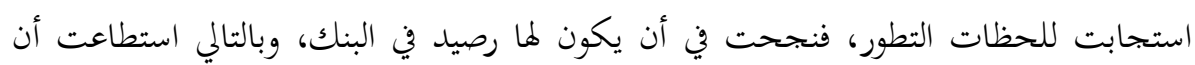

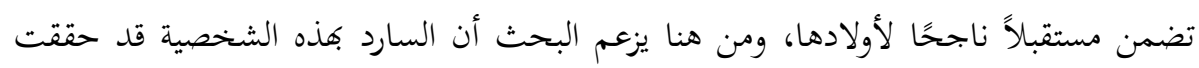

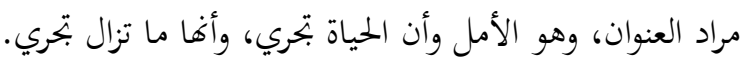

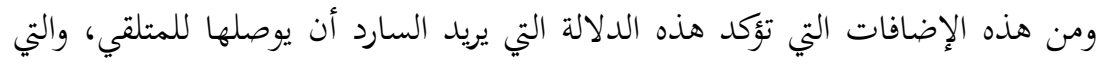

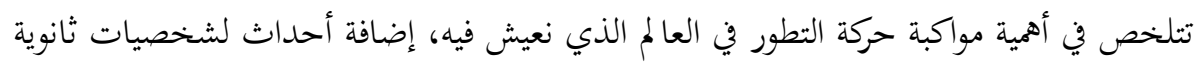


توجد في الحدثين، ومن أمثلته هذه الإضافات لشخصيتي "مودة" و "شهيرة"، والتي فيها يصور

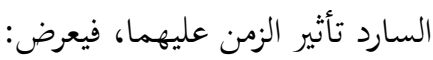

\section{r-Y-Y شخصية "حمودة":}

يزعم البحث أن شخصية ممودة في الحدث الروائي للروايتين تقوم بوظيفة الصديق

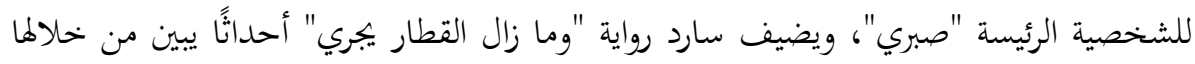

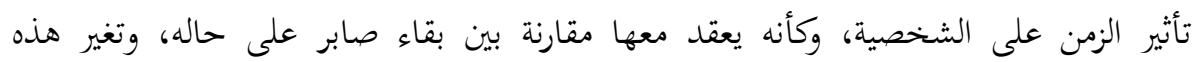

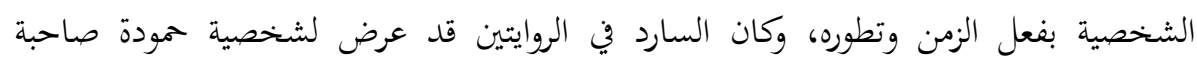

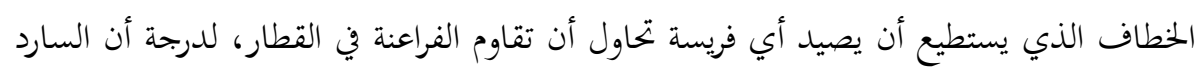

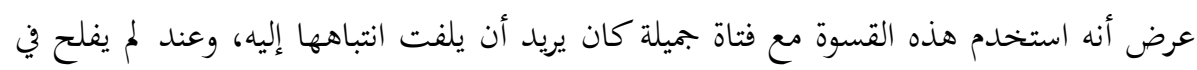

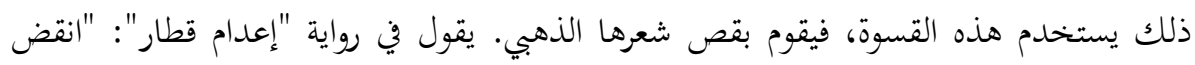

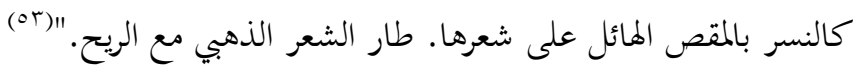

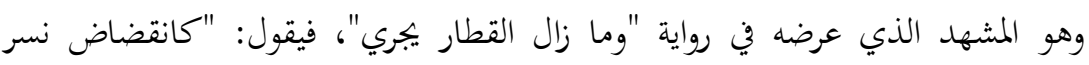
انقض على شعرها أحاطت به يده بكامله، وباليد الأخرى مقص هائل الحجم أتى على شعرها كله. "(0)

هذه الشخصية بهذه الكيفية يضيف لها سارد "وما زال القطار يجري" رؤية أخرى، وفيها

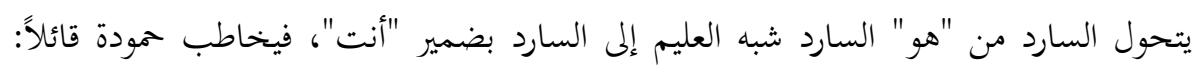

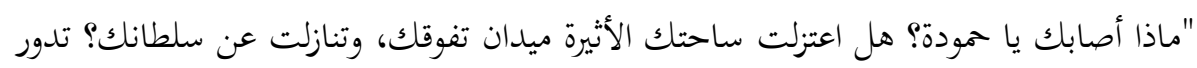

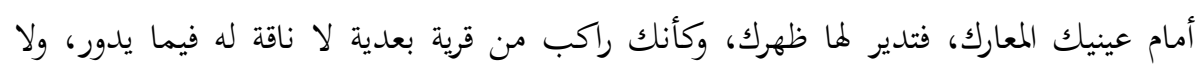

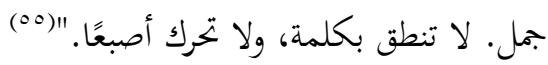

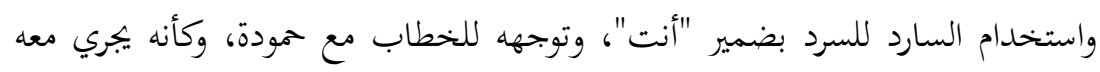

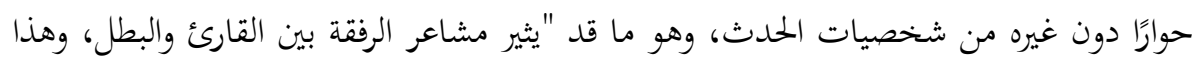

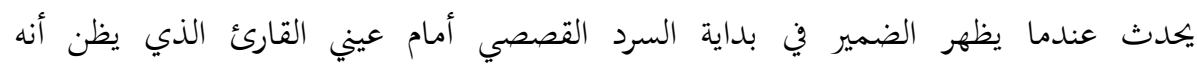

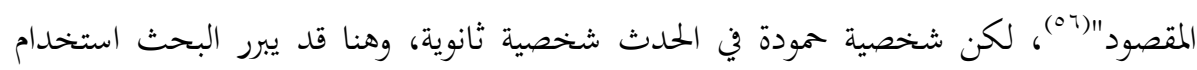

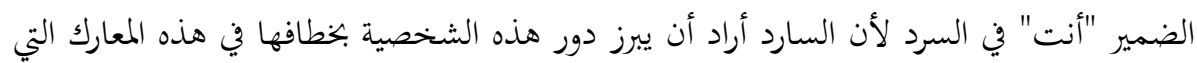

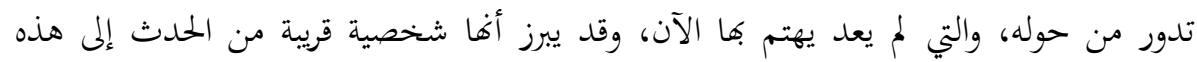

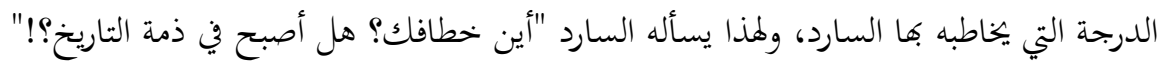


ويوضح لنا السارد العليم السبب في أنه جُند "التجنيد الإجباري بعد أن أهى دراسته المتوسطة في عدد قياسي من السنوات. يُرى راكبًا بين الحين والحين مرتديَّا ملابس التجنيد، وغيرها

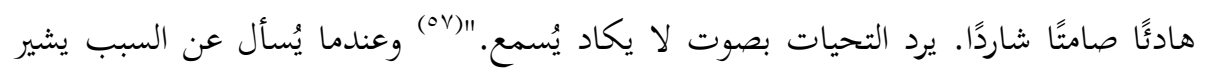
إلى أنه "كنت جاهلاً وعقلت.

وكأن السارد بهذه الإضافة يؤكد تأثير الزمن في تغيير الشخصيات حتى الشقية منها، وليعقد مقارنة بين هذا التغيير، وثبات شخصية صابر على حالها في حب القطار.

\section{r r-r}

من الشخصيات التي أضاف إليه سارد "وما زال القطار يجري" أحداثًا تؤكد - كما عند حمودة- تأثير الزمن عليها شخصية شهير، وهي من الشخصيات التي يرى البحث أن وظيفتها في الحدث الروائي في الروايتين هو تعمير الحدث، لأنه "فما دامت الرواية معنية بتقليم البيئات

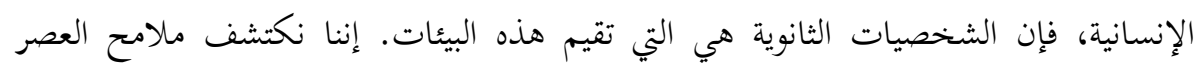
والبحتمع عندما نراقب الشخصيات الثانوية، وهي تنطلق خلال أعمالها المألوفة"|(م). فلقد سبق أن عرض السارد أن شخصية شهيرة تتمتع بالضخامة، وطول اللسان سواء أكان العرض في "إعدام قطار" أو في "وما زال القطار يجري"، لكنه في الرواية الثانية يضيف إلى الحدث مشهدًا بأسلوب التلخيص، وفيه يعلن عن مقابلة صبري لشهيرة، واندهاشه لرؤيتها، وقد فقدت الكثير من وزها، وأصبح لساها عفيفًا، فيقول: "وقف مشدوهًا لا يصدق ما يراه... أهذه هي؟ لا يمكن أن تكون. كيف يذوب الإنسان كل هذا الذوبان في بضعة أشهر؟ قبل شهور كانت في ضخامة فيل طويلة عريضة عفيَّة يخشاها الرجال. أهذه شهيرة التي كان لا يقاوم دفعتها الشهيرة في العربة المكشوفة الرجل القوي، فيسقط، فيقهقه الناس؟ ظهرت نتوءات عظم وجهها، وغارت عيناها الواسعتان المقتحمتان، وذهب لوها الوردي تاركًا بحاله للون طمي كئيب. أمسكت شهيرة يد صبري الممتدة إليها بكلتا يديها، وأمطرت

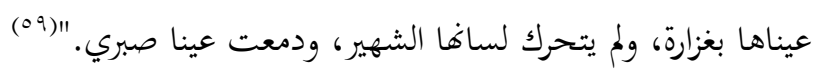
ففي ثنتا وثمانين كلمة يعرض السارد للفرق بين ماضي شهيرة، والذي سبق عرضه بالتفصيل في الحدث الروائي، وبين هذا الحاضر الذي وصلت إليه، وينهي هذا التلخيص بنقطتين؛ أولاً: يصف شهيرة من وجهة نظر صبري، وهو وصف حاول فيه أن يجمع بين وصف ما يراه اليوم أمامه، وبين ما كانت عليه بالأمس، فاليوم يرى أن نتوءات عظم وجهها قد ظهرت، ويفه وصهم

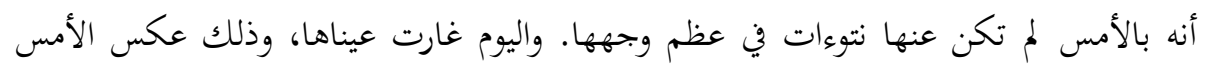


الذي يصوره بأن عيناها كانت واسعتان مقتحمتان، واليوم أصبح لوغا بلون الطمي الكئي، وكان بالأمس ورديَّا.

ثانيًا: تمسك شهيرة يد صبري بكلتا يديها، وتبكي بغزارة، فكأنه بكاء على الزمن الماضي

$$
\text { بكل ما فيه من إيجابيات وسلبيات، وتدمع عينا صبري، رحمة بما وصلت إليه. }
$$

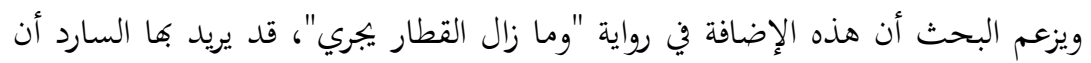

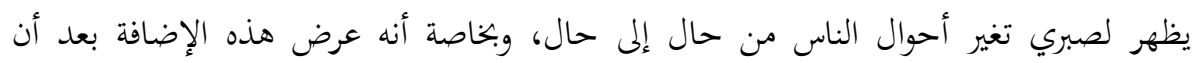

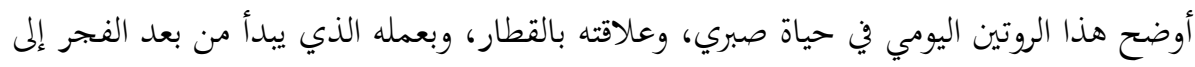

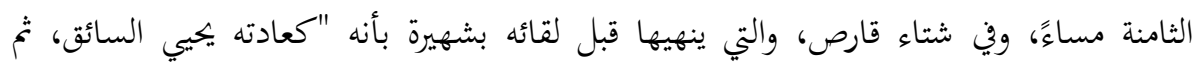
يصعد إلى عربة من عربات القطار ليلقي نظرة سريعة، ثم يهبط ليعطي السائق الإذن فئن

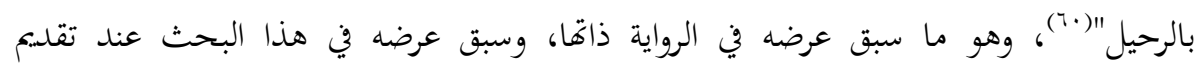

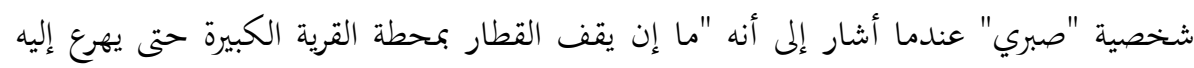

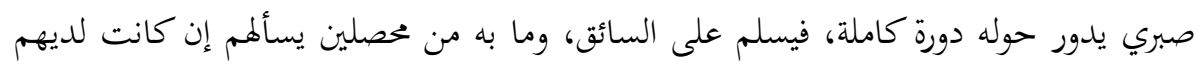
مشكلة أو يحتاجون لأية مساعدة".

ويزعم البحث أن السارد أراد من صبري أن يفكر في نفسه، لأن بحال العمر قليل، والزمن

يلعب دوره في مهارة، ولا يُبقي على أحد، وقد تكون شخصية شهيرة في هذا الموقف قناعًا يختبئ

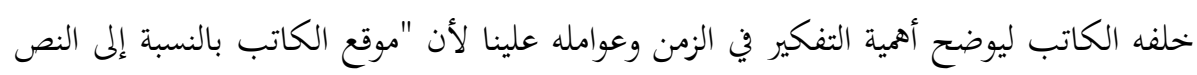

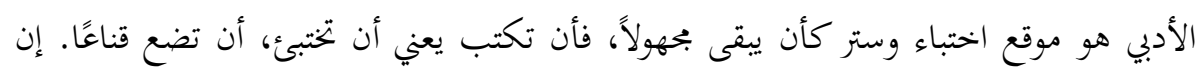

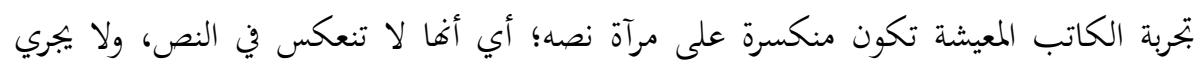

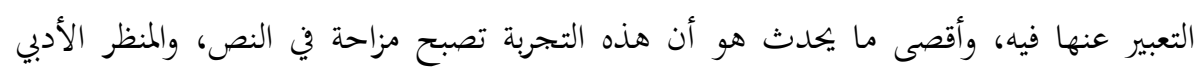

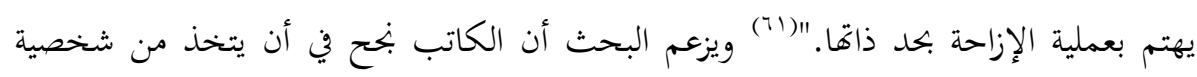

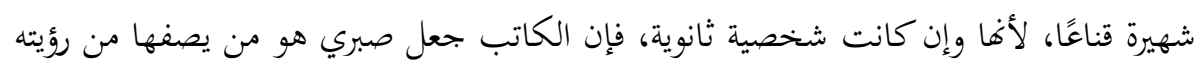

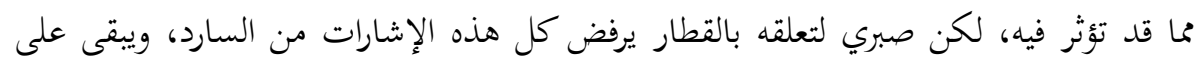
تمسكه بحب القطار.

\section{r-r}

من الشخصيات التي أضافها سارد "وما زال القطار يجري" شخصية ملهودية الشيخ محمود وجيه

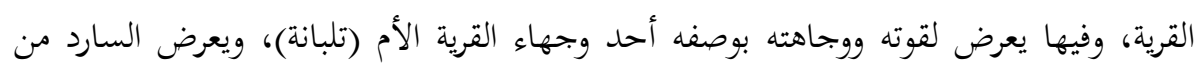

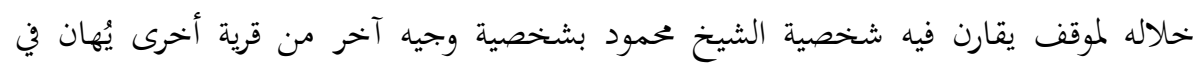


القطار من أحد أفراد القرية الأم، فيقول: "وجهاء القرية الأم يحتفظون بوجاهتهم في القطار. لهم فيه ما لمم من الاحترام في القرية، عكس وجهاء القرى القبلية. على هؤلاء أن يتناسوا في القطار وجاهتهم، وعليهم الخوف من أن ينالهم السوء من جهل جاهل أو نزق مراهق يبحث عن اعتراف

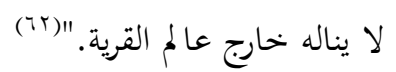

بعد هذه المقدمة التي أوضح أن وجهاء القرى القبلية عليهم أن يخافوا من الإهانة، وحدد المداء

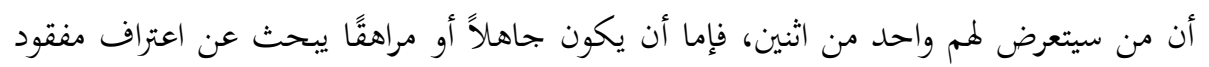
في قريته. يقدم لنا السارد شخصية الشيخ محمود، ودوره في عالم القرية، فيقول: "يتوجه الشيخ محمود وجيه من وجهاء الصين إلى القطار وبصحبته بعض رجال القرية، وبعض النساء إلى القطار

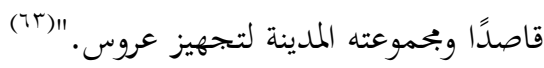
ويعود السارد ليمهد لهذا اللقاء بين الشيخ محمود ووجيه آخر من وجهاء القرى القبلية، فيشير إلى أنه معروف في قرى كثيرة، لأنه عضو بلجنة المصالحات التي "تحمل على عاتقها فض المنازعات الكبيرة التي تحدث بين قرية وقرية أو بين عائلة كبيرة وعائلة مثيلة في قرية من القرى." وبهذا يكون معرفته بهذا الوجيه شيئًا طبيعيًا، وهو ما يعرضه في لقائه بزميل له في تلك اللجنة، فيقول: "في القطار التقى الشيخ بزميل له في تلك اللجنة يقطن قرية بعيدة ذاهب هو الآخر في

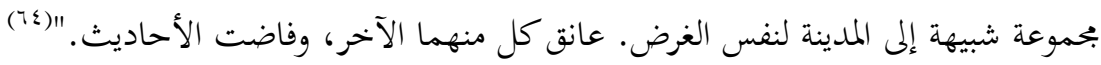
ففي هذا المشهد قدم السارد إلى مساواة بين الشيخ محمود، وهذا الوجيه، فهما معًا عضوان في لجنة المصالحات، وهذه مساواة أولى، والمساواة الثانية تأتي من أن السارد عرض أن هذا الوجيه يصطحب بحموعة شبيهة بمجموعة الشيخ محمود، والغرض واحد بينهما، وهو بتهيز العروس من عالم المدينة. لكن ما يحدث بعد ذلك يوضح أن هناك فارقًا واحدًا بين الاثنين، ويتمثل هذا الفارق في مدى الاحترام الذي يلقاه كل منهما في عالم القطار، فالشيخ محمود لأنه من القرية الأم يلقى هذا الاحترام الذي يلقاه في القرية، ولكن هذا الزميل لأنه ليس من القرية الأم فإنه يهان، فيقول:

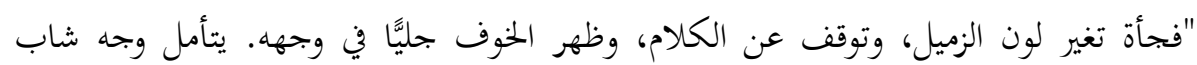
ضخم التكوين لا تفارقه عيناه، كأنما يستمد الرعب من ملامح الشاب. سأله الشيخ محمود عما دهاه.

-مفيش حاجة. - مفيش إزاي لازم تقول. 


\section{- لما نوصل المنصورة أحكيلك على كل حاجة.}

وكف الرجل عن الكلام برهة، وتغير مزاجه. يهاول جاهدًا أن يجاري الشيل الشيخ في

حلديثه. 1"(70)

إلى هنا يقدم لنا السارد خوف هذا الوجيه من الشاب بلمرد رؤيته، ويخشى أن يجكي

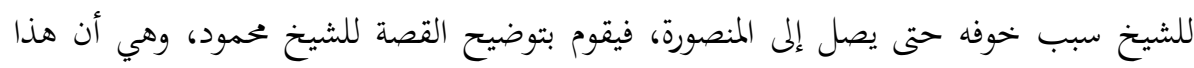

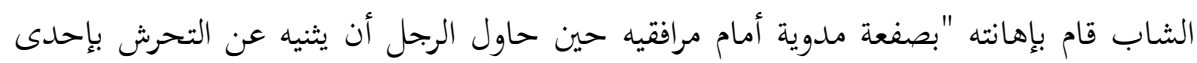

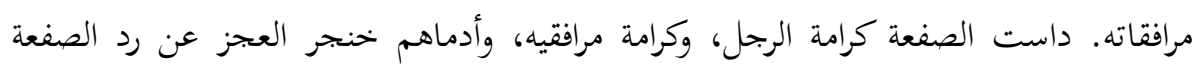
صفعات." (77)

وهنا تكون المقارنة بين الشيخ محمود وهذا الوجيه عندما يُقسم الشيخ محمود على "أن

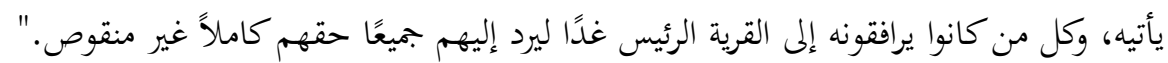

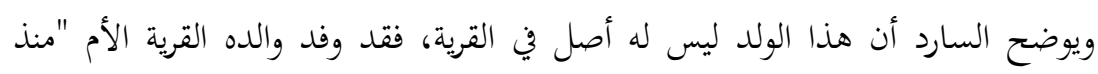

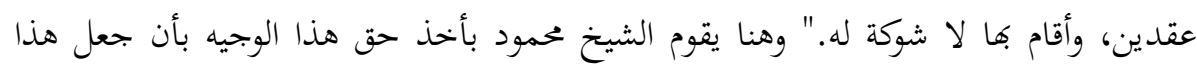

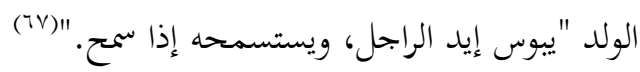

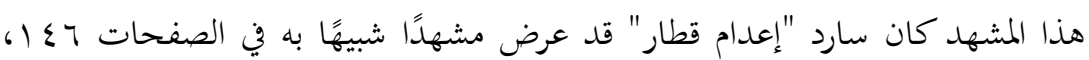

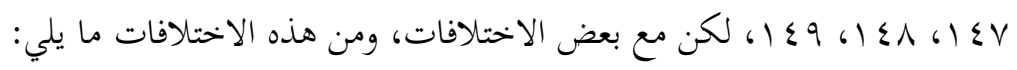

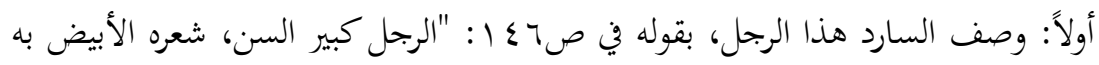

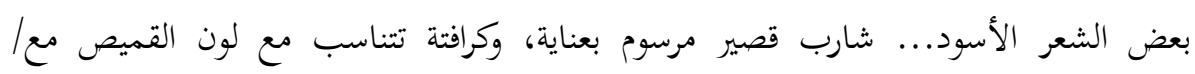
الجاكيت البني الأنيق. يحمل في يده مسبحة، ويتمتم بكلمات التسبيح."

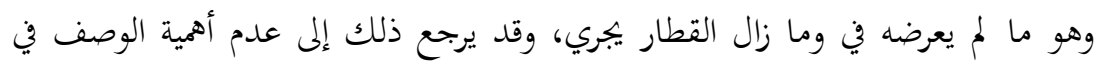

هذا المشهد.

ثانيًا: الولد أهان هذا الرجل بالكلمات، ولم يصفعه، فقد صور السارد هذه الإهانة في

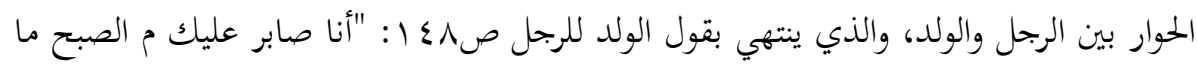

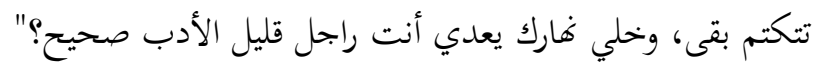

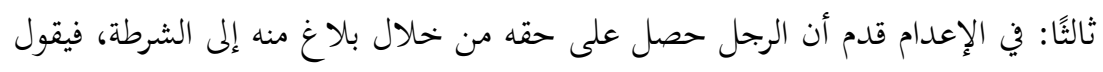

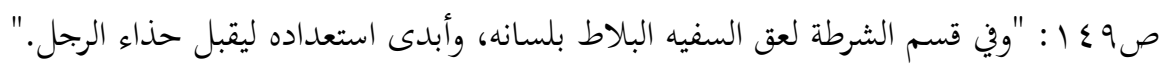

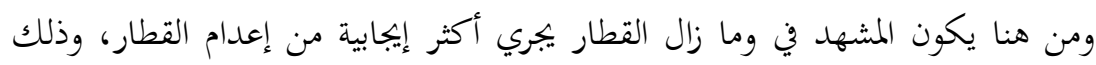

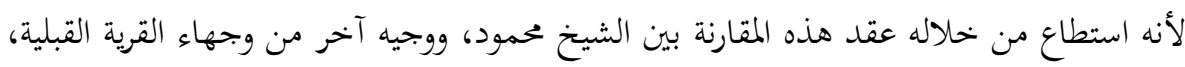


وأكد ما سبق عرضه بأن الذي سيتحرش بهؤلاء الوجهاء هو نزق مراهق ليس له دور في القرية

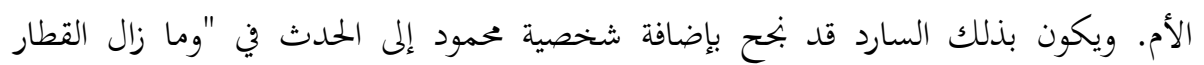
يجري". وتكون شخصية الشيخ محمود في رواية "وما زال القطار يجري"، من الشخصيات الثانوية

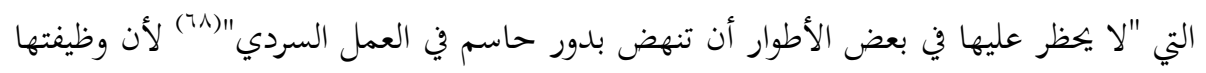

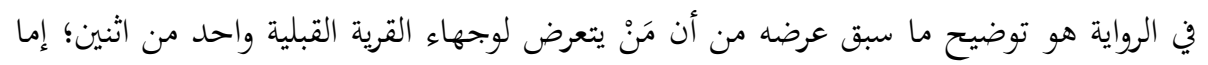

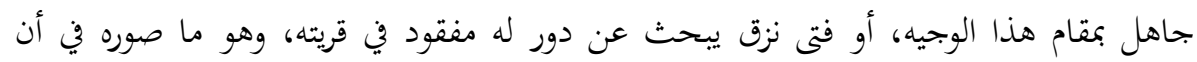

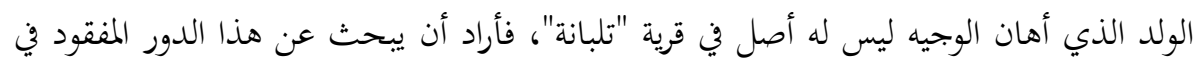
قريته.

\section{Y ب إضافة اسم علم لشخصيات ثانوية:}

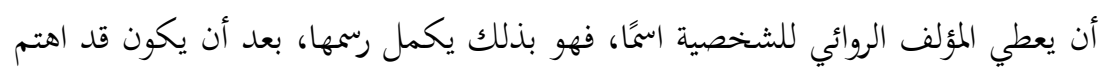

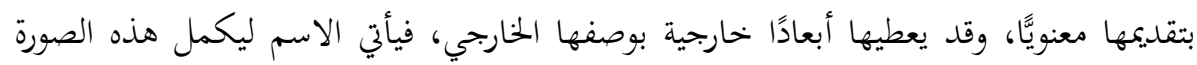

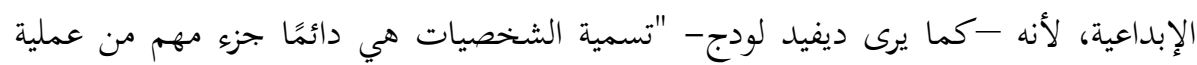

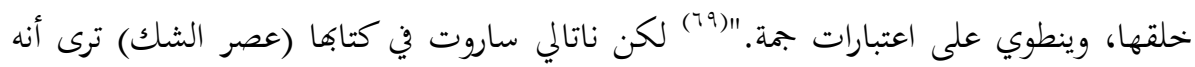

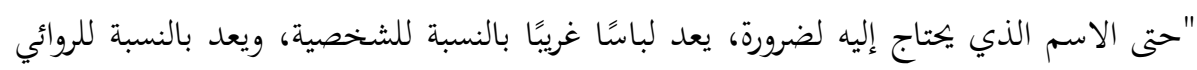

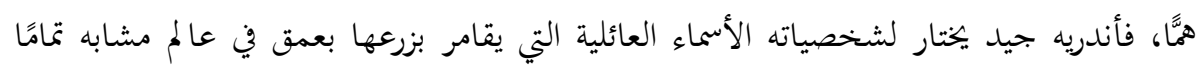

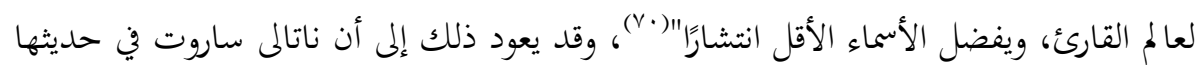

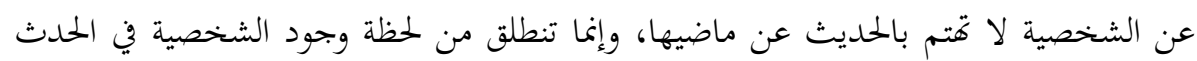

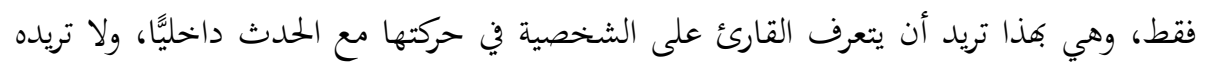

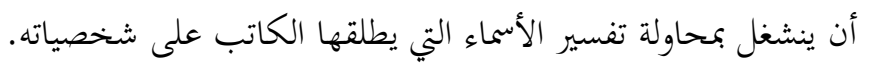

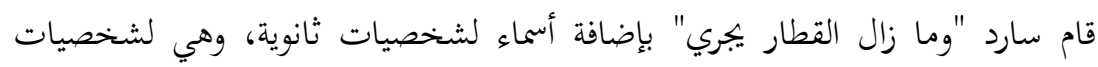

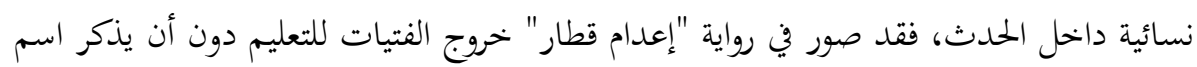

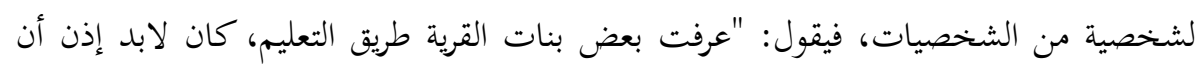

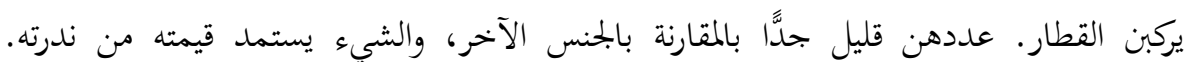

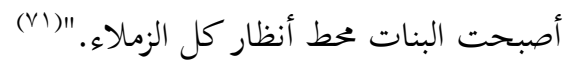




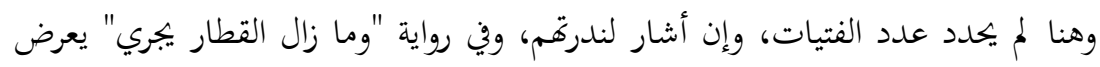
لهذا المعنى، فيقول: "يستمد الشيء قيمته من ندرته. قلة من البنات دفعت بهن قراهم والقرية الأم

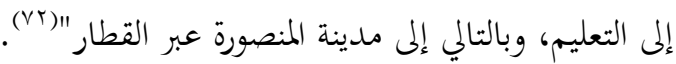
يخصص من هؤلاء الفتيات ثلاث، ويحدد لهم الأسماء، بل يصفهم، فالفتاة الأولى يسميها

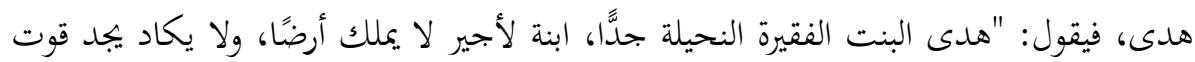
يومه. أصر والدها على تعليمها. لا تسلم من التعليقات الساخرة في غدوها إلى المحطة ورواحها.

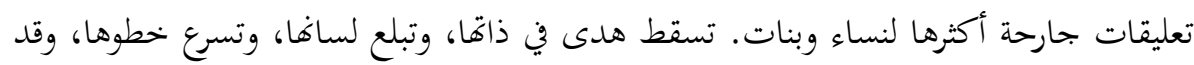

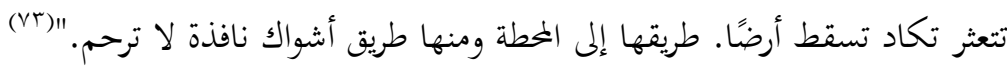

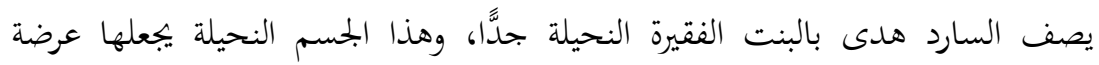

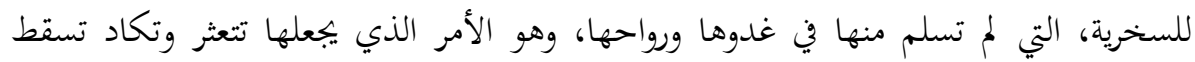
أرضًا.

وعلى عكس شخصية هدى تأتي شخصيتا ماجدة وآمال، فيقدمها السارد بقوله: "أما ماجدة السمينة، فكلها ثقة بنفسها وجمالما المستمد من سمنتها في وقت على عنَّت فيه اللحوم، فعيناها

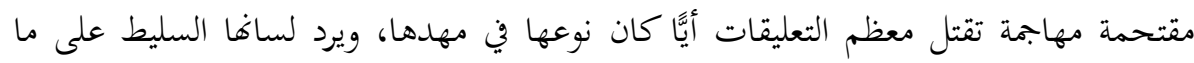

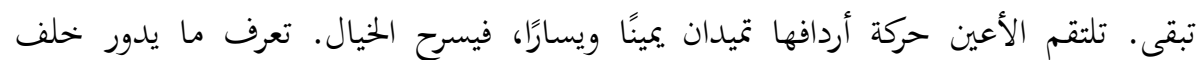

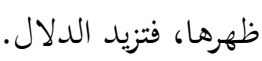

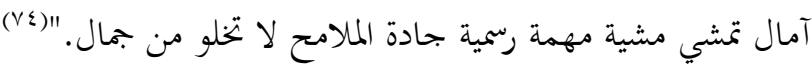

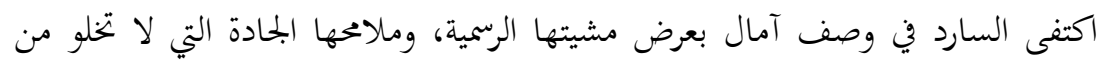

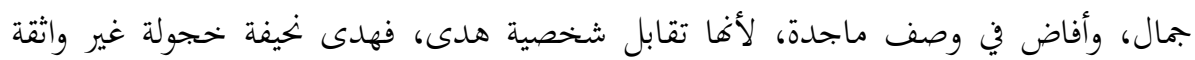

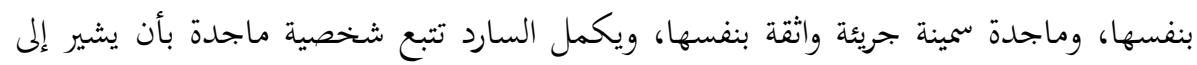

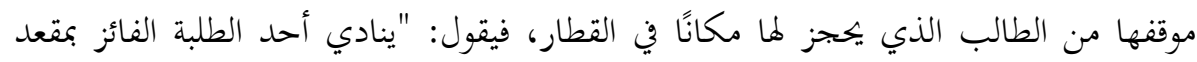
ماجدة السمينة الممتلئة عن آخرها باللحم في زمن عز فيه الخبز. - اتفضلي مكاني.

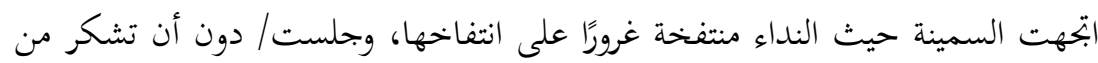
ناداها، أو تنظر إليه، بتعال كأن مناديها خادمها المطيع."(Vo) 
وكان سارد "إعدام قطار" قد بحاهل الإشارة إلى اسم الشخصية، فسرد المشهد دون ذكر

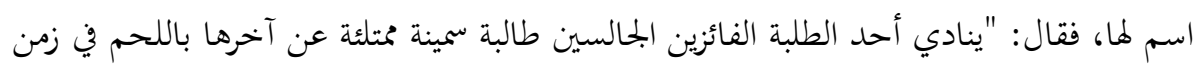

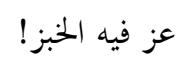
- اتفضلي مكاني.

ابتهت السمينة حيث النداء بكل هدوء، وبوجه جامد خال من التعبيرات لتجلس. لم لمان

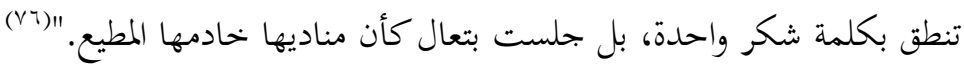

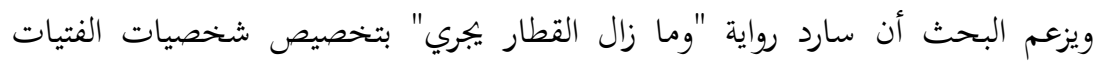

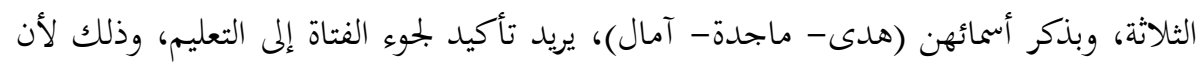

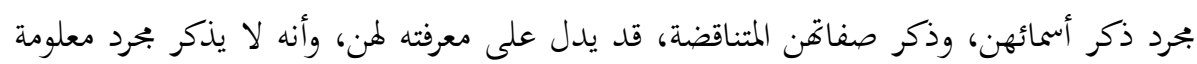

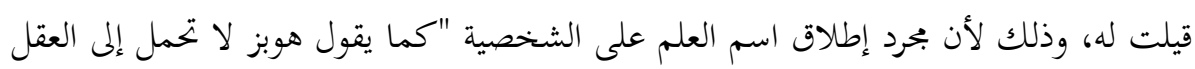

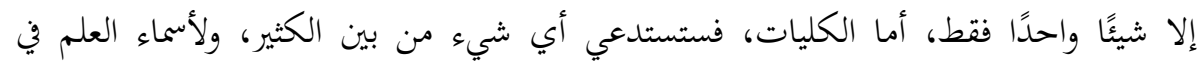

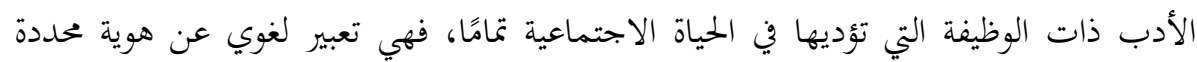

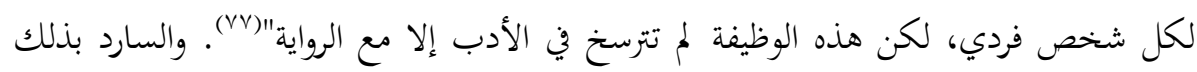

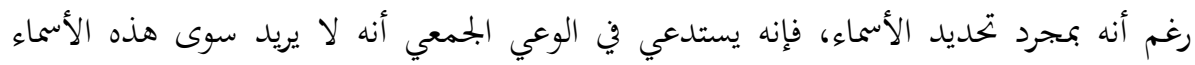

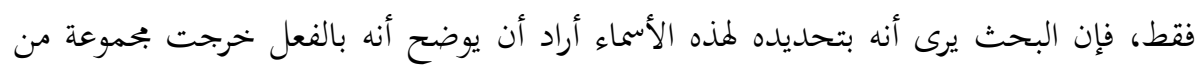

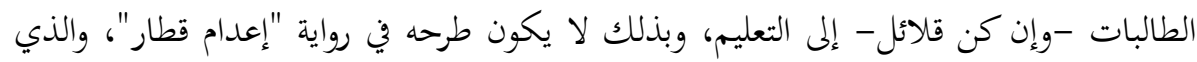

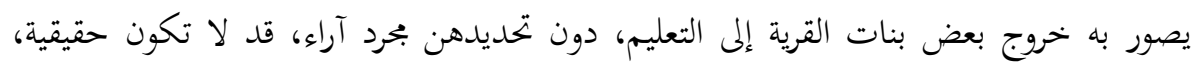

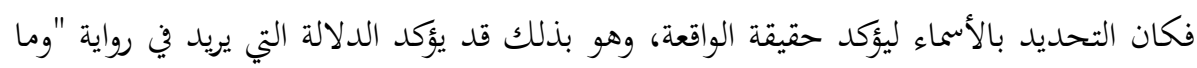

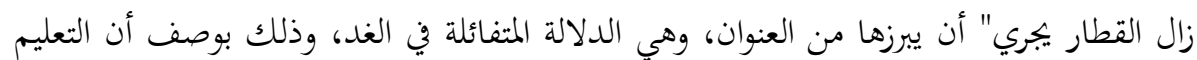
قد يغير من مفاهيم كثيرة في البحتمع المصري. ب- مشهد النهاية بين الروايتين:

يبدأ مشهد النهاية في رواية "إعدام قطار" باعتلال صحة صبري، وهنها بنها يعقد موازاة بين اعتلال صحة صبري، وبين الخسار دور القطار الفرنساوي في حركة المواصلات بين القرية الأم

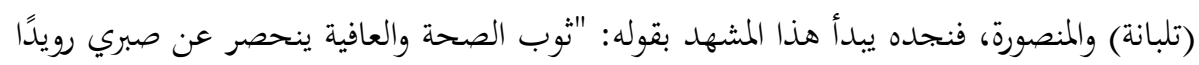

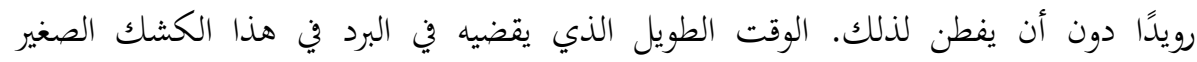
خصوصًا قبيل الفجر. (VA)" 
هذا التغيير في صحة صبري يربطه السارد - كما سبق القول- "بتزايد انصراف الركاب عن القطار يومًا بعد يوم بمعدل غريب" فيتغير مزاج صبري في كشكه، وكأنه تاجر بارت بتحارته. "V9)"

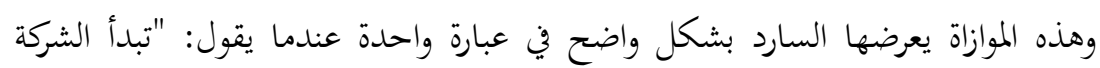
تقليص العمل على الخط الأخير. مستوى صحة صبري يتقلص إلى النصف أيضًا بتوافق غريب.

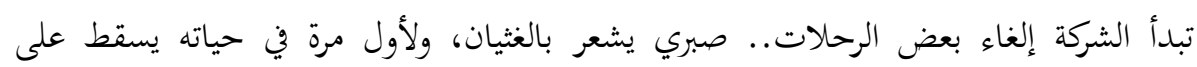

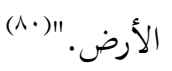
هذه الموازاة توضح أن التمسك بالقيم البالية قد تؤدي إلى الضياع، ومن هنا أوضح السارد أن صبري عندما يقع ينقل إلى المستشفى "في عربة... لم ينقل بالقطار!" فهذا التمسك بالقديم لن يفيد بل التطور في الفكر هو الذي قد يفيد، فيموت صبري، ويربط السارد بين المعشوقين مرة أخرى، فيقول: "إها تصاريف الأقدار يوم مات صبري مات القطار. مات المحب والمحبوب. لا تدري أمات حزنًا على القطار أم مات القطار حزنًا عليه. انتهت قصة حب غرون غريبة

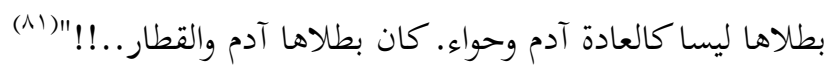
فتكون النهاية في "إعدام قطار" هاية متشائمة تنتهي بالموت (موت صبري- موت القطار)، وهذه النهاية تؤكد تلك الدلالة التي ظهرت من عنوان الرواية "إعدام قطار"، ويزعم

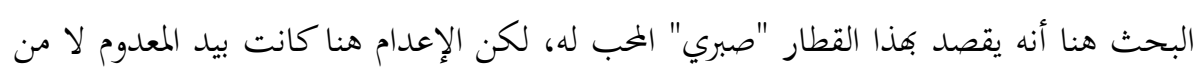
عنصر خارجي. لكن النهاية في "وما زال القطار يجري" كانت مغايرة، فيبدأ مشهد النهاية بتصوير الأمل في الغد، فيقول ص. rا : "بسرعة مدهشة تغير وجه الحياة في القرية الكبيرة. دراجات بخارية تشق الصمت، وتنهب الطريق. سيارات تعرفها القرية بأرقام محلية وخليجية. حتى أدوات الزراعة المتوارثة

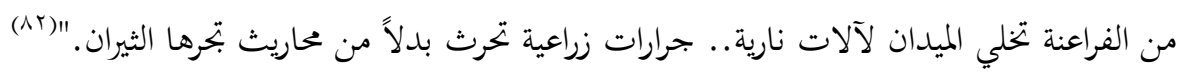
وفي هذه النهاية بنده يعطي للوقت قيمة، ويظهر هذا من خلال الحوار الذي يضيفه بين

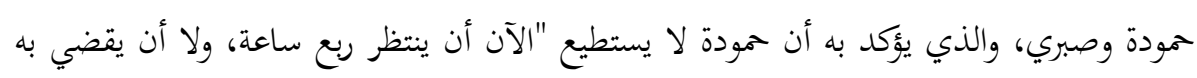

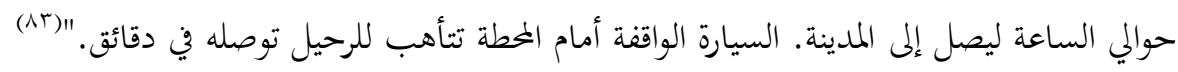
وهذه القيمة للوقت هي التي تجعل السارد يربط بين موت صبري وموت القطار كما في

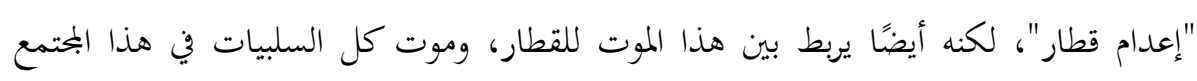
(بحتمع القطار)، فيبدأ بالربط بين موت صبري وموت القطار، لكن بشكل أكثر تفصيلاً، فيقول:

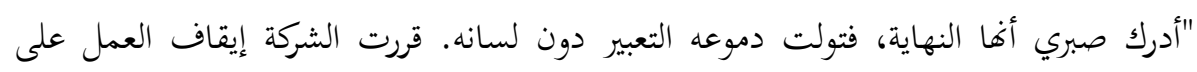


خطها الأخير. صبري يفقد القدرة على الحركة أيضًا كما فقد القطار حركته. الشركة تسرع برفع القضبان. المخ يوقف إرسال إشارات الحركة إلى أعضاء صبري. الشركة تزيل كشك المحطة بالقرية الكبيرة. الحياة تسحب آخر جندي لها من جسد صبري. مات القطار فمات صبري، أو مات

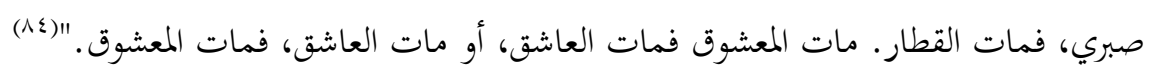
وهذه النهاية، وإن كانت بتفاصيل أكثر محا هي في "إعدام قطار" أراد بها تصوير مدى ارتباط "صبري" بالقطار، فعرض فقده للحركة بإيقاف الشركة لخطها الأخير، وعندما تسرع الشركة برفع القضبان يوقف مخه إرسال إشارات الحركة، وعندما تزيل الشركة كشك المططة بالقرية الكبيرة يموت صبري، ويزعم البحث أن السارد أراد بهذه التفاصيل أن يشير إلى أن صبري كان عنده الأمل في أن تعيد الشركة النظر في هذه الإزالات، وتعود للعمل بالقطار، لكنها تبقى آمال سلبية غير حقيقية، وتبقى أن النهاية فيها هذا التشاؤم الموجود في هاية الإعدام.

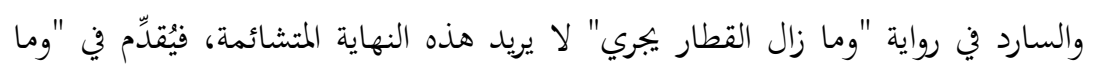
زال القطار يجري" لأساليب القضاء على سلبيات المحتمع، والتي ترتبط بموت هذا القطار، فقد فككوا الكوبري العلوي، فأصبح فارغًا، وبالتالي اختفت السلبيات التي كانت ترتبط به، فقد

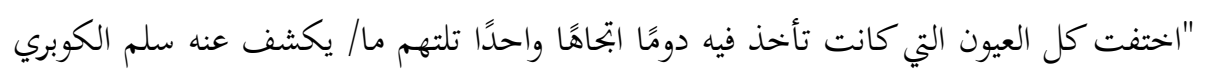

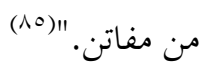
هذه العيون التي كانت تسترق النظر إلى مفاتن النساء، وما تظهره الملابس، هي تصعد على الكوبري. مات القطار، فكانت "شهادة وفاة المقهى الذي كان عامرًا تتهيأ هي الأخرى للإصدار." "(^) كانت شهادة الوفاة للمقهى الذي كان يضيع الوقت بعدما أصبح للوقت قيمة. مات القطار، ف"اختفت عربة صفوت من مكاها الشهير إلى الأبد، وتفرق أفراد عصابته في دروب الحياة." اختفت عربة النصب (عربة صفوت) واختفت عصابة النصب. اختفت السلبيات التي كانت تصاحب القطار، فكأن السارد يعطي الأمل في الغد باختفاء هذه السلبيات، ومن هنا كان هذا السؤال الاستنكاري من السارد عندما يقول: "فهل يجفل تاريخ بأسطورة عشق بين آدمي، وما كان يجري على قضبان؟!" والإجابة المفترضة عن هذا السؤال الاستنكاري معروفة، وهي لا لن يحفل التاريخ بهذه الأسطورة. 


\section{الخحاتمة}

- اشترك السعيد بنم في اختيار غلاف روايتي "إعدام قطار" و"وما زال القطار يجري"، ومن هنا فقد عبر الغلاف عن مضمون الروايتين منذ البداية.

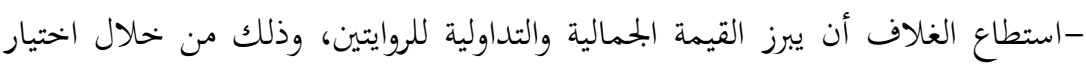
الألوان والصورة المرسومة، وذكر اسم المؤلف صحيحًا، وذكر جنس الكتاب في رواية "وما زال الئل القطار يجري".

- يحمل عنوان رواية "إعدام قطار" تلك الدلالة المتشائمة، وهو ما ظهر في فاية الحدث عندما ارتبط إعدام القطار بموت صبري الشخصية الرئيسة.

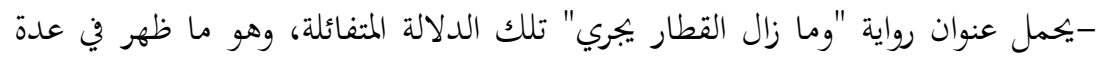

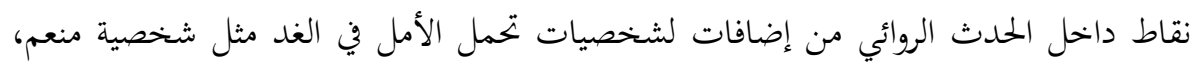

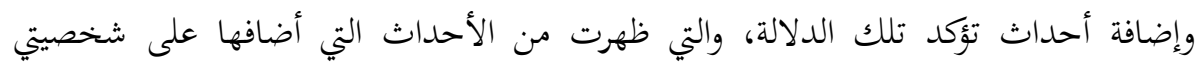
"حمودة وشهيرة"، وتخصيص التعليم للفتيات الثلاثة، والتي تتؤكد أهمية التعليم.

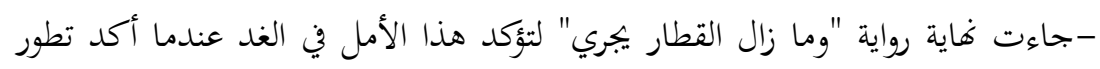
أساليب الزراعة، وموت سلبيات البحتمع بموت القطار. - تغيير عنوان الرواية في الحدثين كان له دوره في تغيير دلالة الحدث، وتحوله من من الدلالة الدات المتشائمة إلى الدلالة المتفائلة. -يرجع البحث إعادة كتابة رواية "إعدام قطار" مرة أخرى بعد عشر سنوات، وتغيير

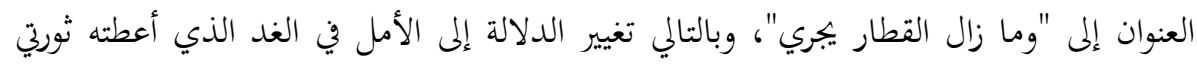

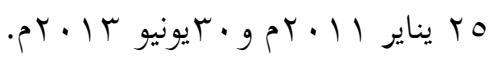




\section{الهوامش:}

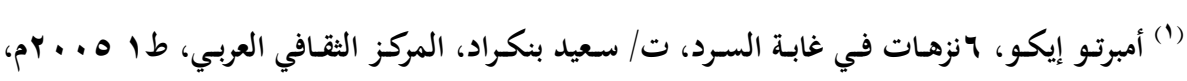

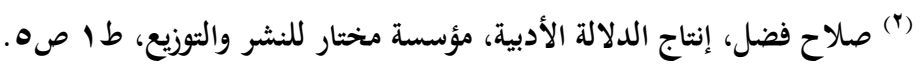

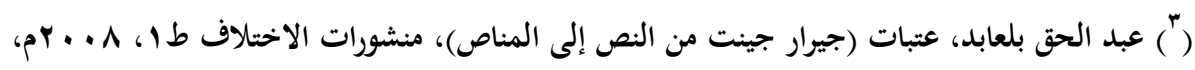

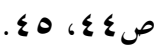

(") سمية زاني، العتبات النصية في رواية ؟ب لأأمير تاج السر، رسالة ماجستير، جامعة محمد خيضر -

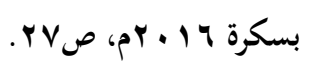

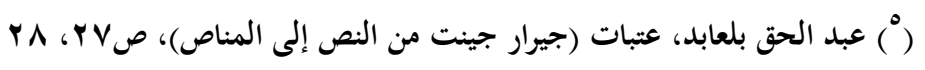
(") عبد الحق بلعابد، عتبات (جيرار جينت من النص إلى المناص)، ص VV

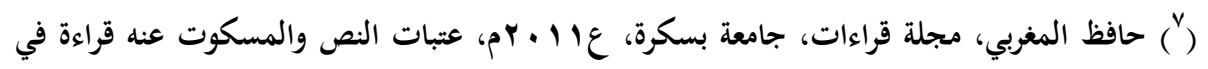
نص شعري، صاعط الن

(") محمد فكري الجزار، العنوان وسيموطيقا الاتصال الأدبي، الهيئة المصرية العامة للكتاب، 991 (م) صی

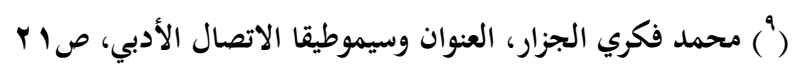

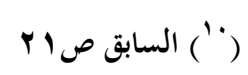

(") سعيد نجم، إعدام قطار، دار إسلام، طا ؟ . . بم صף.

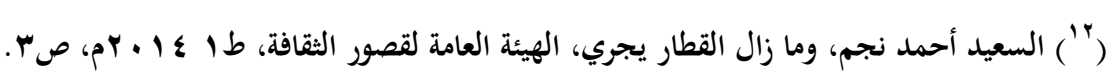

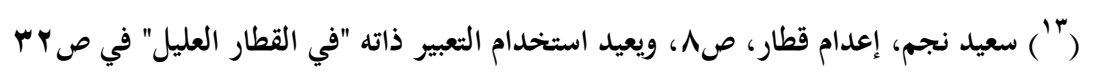
(") (צ') سعيد نجم، إعدام قطار، ص9

(0) انظر السعيد أحمد نجم، وما زال القطار يجري، صه 


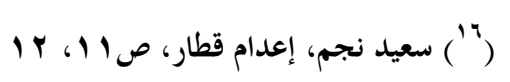

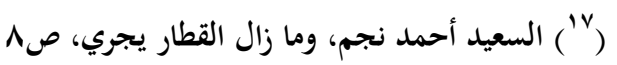

I

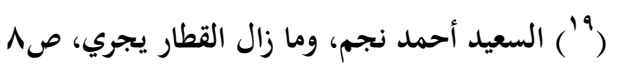

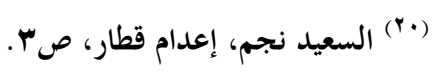

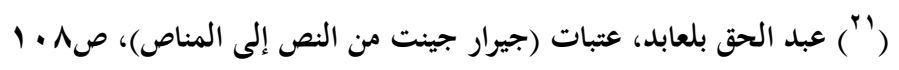

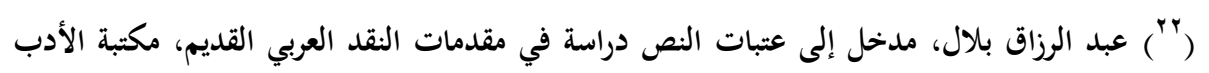

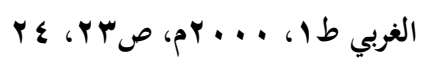

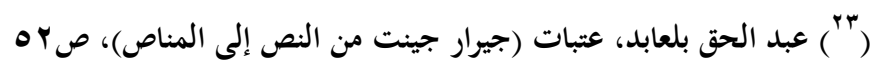

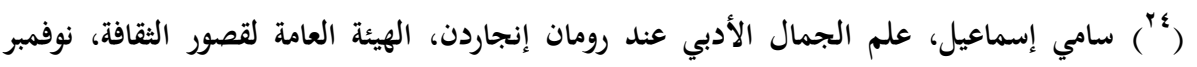

$$
\text { . } 199 \text { (م) (991 }
$$

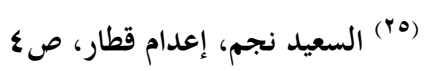

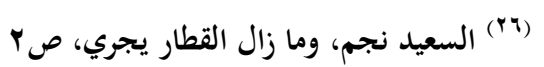

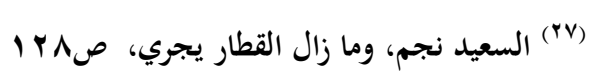

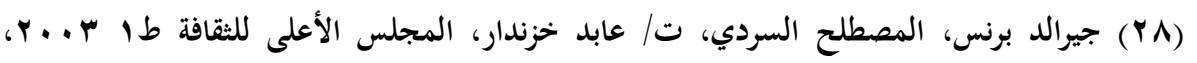

(Y (Y ) والاس مارتن، نظريات السرد الحديثة، ت / حياة جاسم محمد، المجلس الأعلى للثقافة 99 (م)،

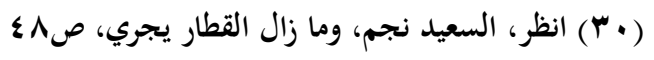

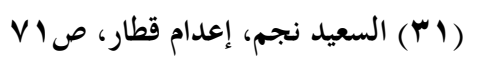




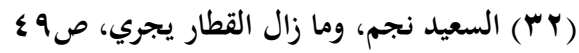

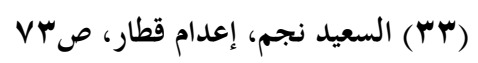

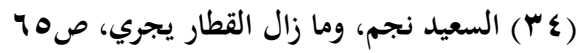

(")" مجموعة من النقاد، نظرية السرد من وجهة النظر إلى التبئير، ت/ ناجي مصطفى، منشورات الحوار

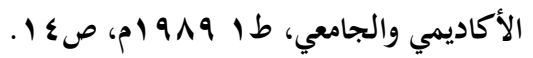

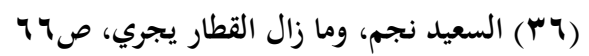

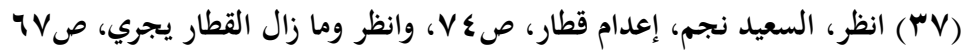

( السعيد نجم، وما زال القطار يجري، صץN)

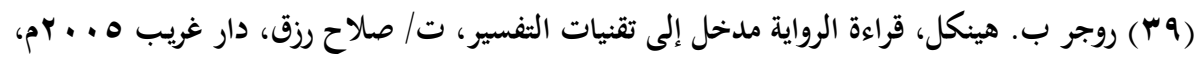
ص

(•) مجموعة من المؤلفين، طرائق تحليل السرد الأدبي، مقال( رولان بارت التحليل البنيوي للسرد) ت حسن بحراوي، بشير القمري منشورات اتحاد كتاب المغرب، طا به 9 ام، (مقال رولان بارت التحليل

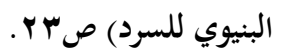

( ) ( السعيد نجم، وما زال القطار يجري، ص ( \& ص (

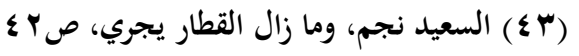

( ) ع ( السعيد نجم، وما زال القطار يجري، صץ ع

(0 ) التلخيص أو الخلاصة، هي ذلك "الجزء من السرد الذي يلخصه، ويحيط بفكرته الرئيسة أو هدفه الرئيسي" انظر في ذلك، جيرالد برنس، المصطلح السردي صه 
وهو "يتولد حينما يعتبر زمن الخطاب أصغر من زمن القصة" انظر السابق صجr Y Yأي أن التلخيص يحمل الرمز (زق > زس)، وهذا يعني أننا نقدم في التلخيص أحداثًا كثيرة، بمدة زمنية طويلة في عدد صفحات قليلة نسبية.

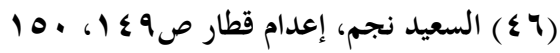

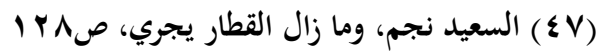

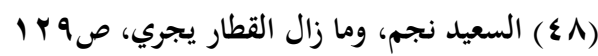

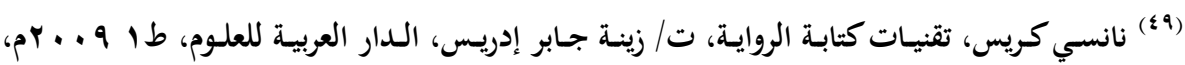
ص

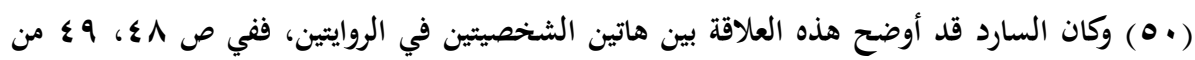
"إعدام قطار" يقدم السارد لمشهد بين شخصية شاب نحيف، وشخصية طالبة ثمينة، فيبدأ المشهد فيه

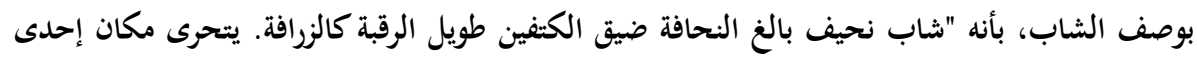
البنات السمينات قبل أن يركب، فإذا وجدها توجه إلى حيث تجلس بعد أن يصفف شعره بمشط أسود

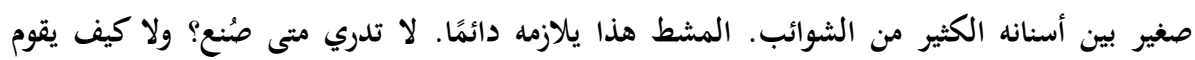
بوظيفته؟! يدهن شعره بزيت غريب الرائحة غريب مصدره."

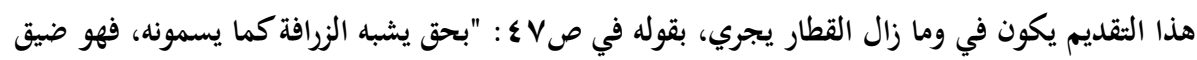

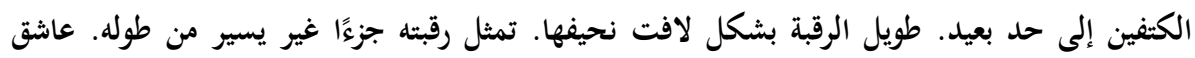
للسمينة طويلة اللسان مدله. ربما أعجبه فيها ما يفتقده في نفسه بشدة؛ لحمها المكتنز . يتحرى مكان إندان ركوبها، ويدس نفسه فيه. عيناه معلقة بها. يتيه. يخرج مشطًا قديمًا متاكلة معظم أسنانه، وتغزو الشوائب لئب

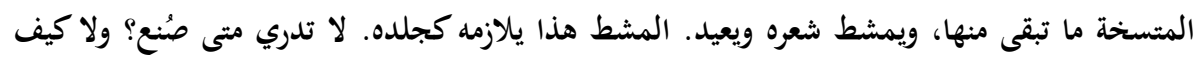

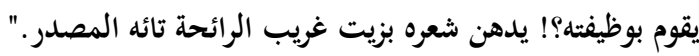
والفرق بين المشهدين هو أنه جعل وصف الشخصية في وما زال القطار يجري نابعًا من الشخصيات الأخرى في الحدث، وليست من السارد كما في "إعدام قطار"، فنراه يقول "كما يسمونه".

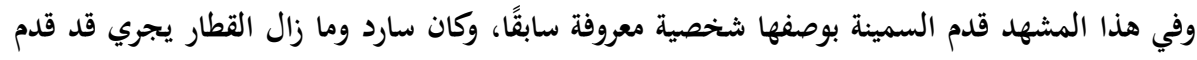
لها في صه ب، بأنها "ماجدة السمينة" في قوله: "ينادي أحد الطلبة الفائز بمقعد ماجدة السمينة الممتلئة عن آخرها باللحم."، وكان في الإعدام قد قدمها بوصفها "إحدى الطالبات"، فجعلها شخصية مجهولة. 
لم يركز سارد وما زال القطار يجري على نحافة الشخصية، ولا على أسنانه المتسخة، ربما لأن النحافة قد تدرك من طوله الذي وصفه بأنه كالزرافة، وقد يدرك من قوله إنه "ربما أعجبه فيها ما يفتقده في نفسه

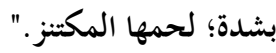
وفي نهاية المشهد يقدم السارد في الروايتين أن هذا الزرافة يحاول افتعال مشاجرة مع أحد الواقفين ليلفت

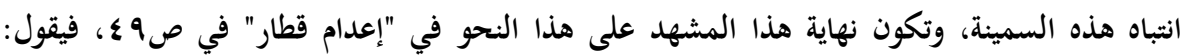
"ويحاول الانقضاض على زميله، بينما السمينة تمط شفاهها. يتدخل أحد الموظفين الذي ضايقه صوت

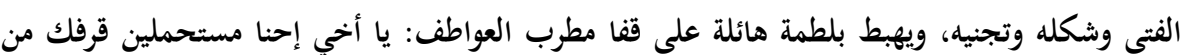
ساعتها. قلنا يمكن يكون عندك شوية دم، وتبطل لوحدك لكن يظهر مفيش فايدة." وتكون النهاية في وما زال القطار يجري بتحديد أن من عنف الشخصية هو "منعم"، وبأنه طلب منه لنه أن

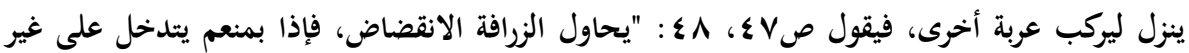
عادته: - استنى عندك.. انزل اركب في عربية تانية.. مستحملين قرفك من ساعتها، يمكن يكون عندك شوية دم، ومفيش فايدة." ويكون تدخل السارد بالتعديل هنا منطقيَّا، وبخاصة أنه سبق وعرض أن لمنعم قوته، وهنا عرض أنه تدخل

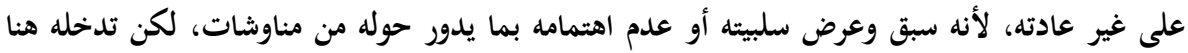
يبرز للمتلقي مدى الأذى الذي سببه هذا النحيف في مجتمع القطار.

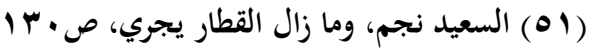

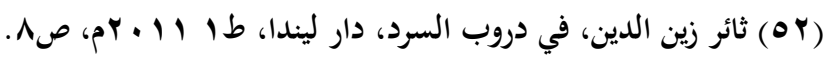

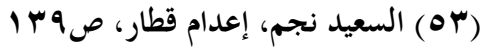

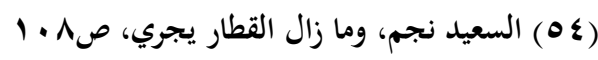

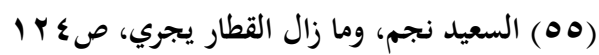

(†ه ) إنريكي أندرسون إمبرت، القصة القصيرة النظرية والتقنية، ت/ علي إبراهيم علي منوفي، م/ صلاح

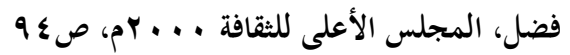
السعيد نجم، وما زال القطار يجري، صـ (OV)

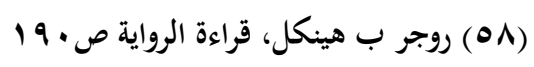




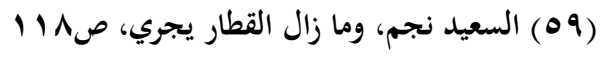

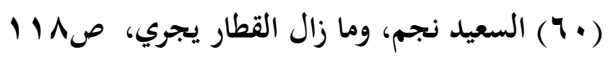

( الا) جون ليشته، خمسون مفكرًا أساسيًّا معاصرًا من البنيوية إلى ما بعد الحداثة، ت/ فاتن البستاني،

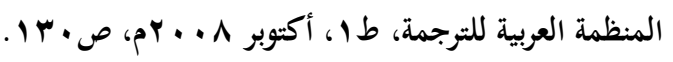

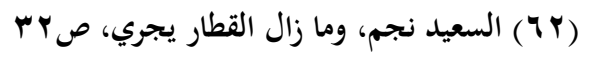

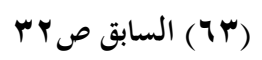

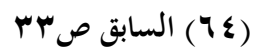

(10) ( السعيد نجم، وما زال القطار يجري، صبr

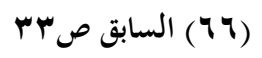

(TV) (TV السعيد نجم، وما زال القطار يجري، صع

(1) (4) عبد الملك مرتاض، في نظرية الرواية، بحث في تقنيات السرد ، سلسلة عالم المعرفة، الكويت، ديسمبر

$$
1 \cdot 19 \text { (1991 }
$$

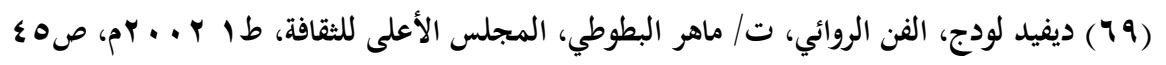

الناتلى ساروت، عصر الشك دراسات عن الرواية، ت/ فتحي العشري، المجلس الأعلى للثقافة، ط• (V•)

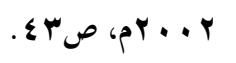

$$
\text { 1 السعيد نجم، إعدام قطار، ص (VI) }
$$

السعيد نجم، وما زال القطار يجري، ص؟ (VY)

$$
\text { V السابق، ص (V) }
$$

V السعيد نجم، وما زال القطار يجري، ص) 


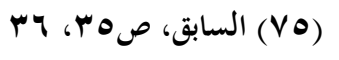

(VY)

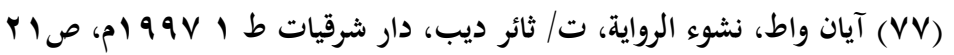

$$
\begin{aligned}
& \text { السعيد نجم، إعدام قطار، صبه (VA) } \\
& \text { السابق، صع (V9) }
\end{aligned}
$$

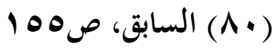

lov السعيد نجم، إعدام قطار صI)

I السعيد نجم، وما زال القطار يجري، صr) (AY)

هذه الإشارة إلى تغير أساليب الزراعة في نهاية الحدث تؤكد هذه الإضافات من سارد "وما وال القطار يجري"؛ حيث أضاف السارد في الرواية إضافات تؤكد تطور أساليب الزراعة، وبدأها في ص. الرواية، عندما يشير إلى أن الفقر في القرية سببه الرئيس هو الاعتماد على الزراعة بأساليبها الفرعونية، فهو يبرز منذ بداية الحدث أن عدم التطور في أساليب الزراعة يؤدي إلى الفقر، فيقول: "الفقر يتسلط على القرية كسائر القرى، فلا دخل غير الزراعة بأساليبها الفرعونية، فهي على حالها لم تتغير؛ حتى الثادوف أول آلة عرفتها البشرية لرفع مياه الري إلى الأرض العطشى ما زال في دائرة العمل."، ويؤكد السارد هذا المعنى مرة ثانية في ص9 1، عندما يشير إلى شقاء الفلاحين من هذه الأساليب البالية، فيقول: "عجيب أن يتعذب الناس وسط الجنان.. شقاء حقيقي تحت قيظ الشمس أو زمهرير الثتاء بأساليب بالية، وأدوات اخترعها الفراعنة، فبعدهم جفت منابع التطوير."، وهذه الجملة الأخير "فبعدهم جفت منابع التطوير" تؤكد أن سارد "وما زال القطار يجري" يبحث عن التطوير في أساليب الزراعة بوصفها إحدى

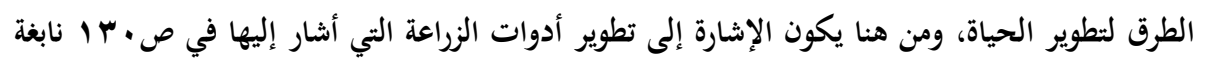
من هذه الرؤية المثفائلة التي يبحث عنها السارد، ويبقى أنها إضافات في حدث "وما زال القطار يجري". السعيد نجم، وما زال القطار يجري، صبr) 


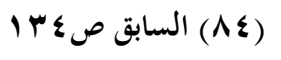

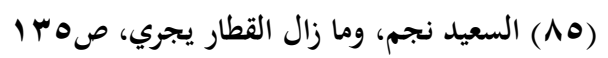

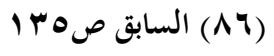




\section{المصادر والمراجع}

\section{أولاً: المصادر}

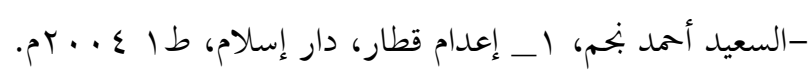

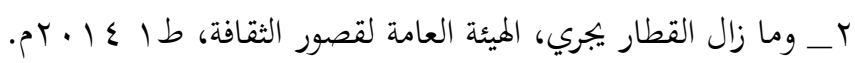

\section{ثانيًا: المراجع العربية}

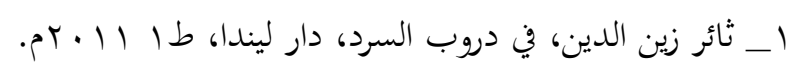

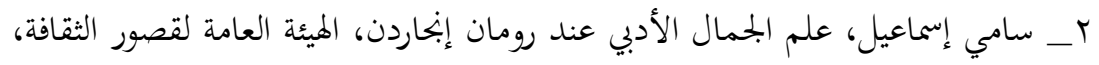

نوفمبر 991 1م.

r_ صلاح فضل، إنتاج الدلالة الأدبية، مؤسسة مختار للنشر والتوزيع، طا ـا.

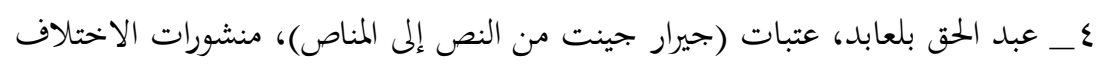

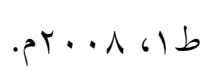

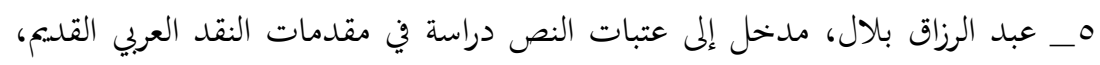

$$
\text { مكتبة الأدب الغربي طا، عبد المزاق بلال، مدخل }
$$

7ـ عبد الملك مرتاض، في نظرية الرواية، بحث في تقنيات السرد ، سلسلة عالم المعرفة،

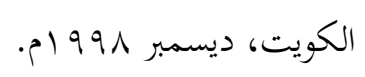

V_ _ محمد فكري الجزار، العنوان وسيموطيقا الاتصال الأدبي، الهيئة المصرية العامة

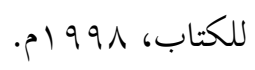

\section{ثالثًا: المراجع الأجنبية}

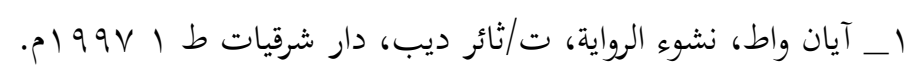

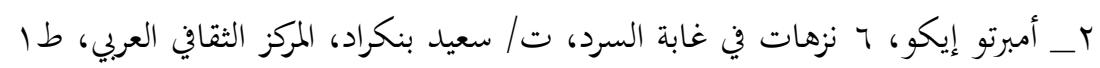

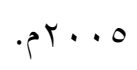

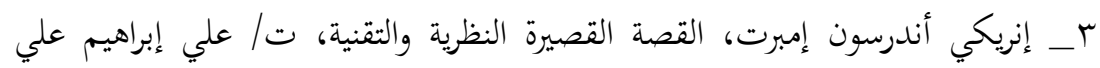

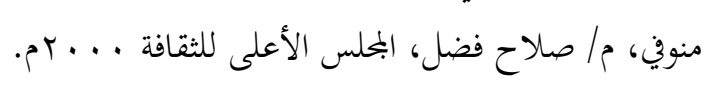

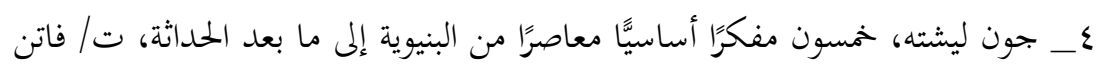

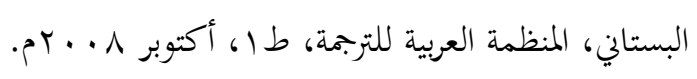


•_ جيرالد برنس، المصطلح السردي، ت/ عابد خزندار، المجلس الأعلى للثقافة طا $. r . . r$

7ـ روجر ب. هينكل، قراءة الرواية مدخل إلى تقنيات التفسير، ت/ صلاح رزق، دار

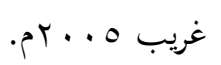

V _ _ بمموعة من النقاد، نظرية السرد من وجهة النظر إلى التبئي، ت/ ناجي مصطفى،

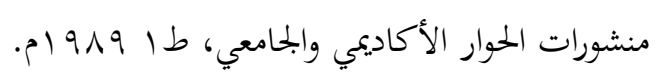

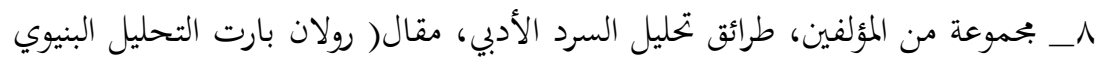

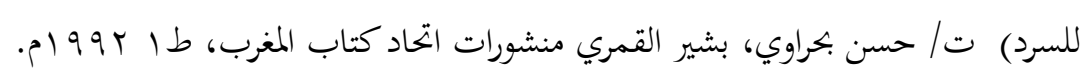

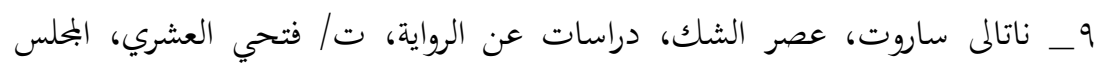

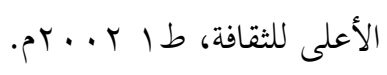

• إ_ نانسي كريس، تقنيات كتابة الرواية، ت/ زينة جابر إدريس، الدار العربية للعلوم،

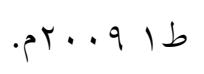

|' إلـ والاس مارتن، نظريات السرد الحديثة، ت/ حياة جاسم محمد، المجلس الأعلى

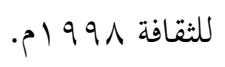

$$
\text { رابعًا: رسائل علمية }
$$

_ سمية زاني، العتبات النصية في رواية ب74 لأمير تاج السر، رسالة ماجستير، جامعة

$$
\begin{aligned}
& \text { محمد خيضر - بسكرة } 7 \text { أ ب بم. } \\
& \text { خامسًا: دوريات علمية }
\end{aligned}
$$

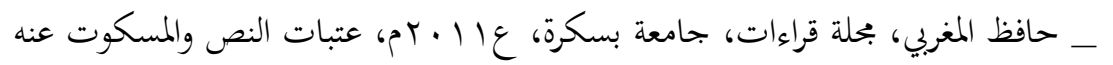

$$
\text { قراءة في نص شعري. }
$$

